November 29, 2008

\title{
The “Impossible Trinity” Hypothesis in an Era of Global Imbalances: Measurement and Testing
}

\author{
Joshua Aizenman* \\ UCSC \& the NBER
}

\author{
Menzie D. Chinn** \\ University of Wisconsin \& the NBER
}

\author{
Hiro Ito $* * *$ \\ Portland State University
}

\begin{abstract}
We develop a methodology that allows us to characterize in an intuitive manner the choices countries have made with respect to the trilemma during the post Bretton-Woods period. The paper deals with positive aspects of the trilemma, outlining new metrics for measuring the degree of exchange rate flexibility, monetary independence, and capital account openness, taking into account the recent development of substantial international reserve accumulation. The evolution of our "trilemma indexes" illustrates that after the early 1990s, industrialized countries accelerated financial openness, but reduced the extent of monetary independence while sharply increasing exchange rate stability. This process culminated at the end of the 1990s with the introduction of the euro. In contrast, the group of developing countries pursued exchange rate stability as their key priority up to 1990, although many countries moved toward greater exchange rate flexibility from the early 1970s onward. Since 2000, measures of the three trilemma variables have converged towards intermediate levels characterizing managed flexibility, using sizable international reserves as a buffer, thus retaining some degree of monetary autonomy. Using these indexes, we also test the linearity of the three aspects of the trilemma: monetary independence, exchange rate stability, and financial openness. We confirm that the weighted sum of the three trilemma policy variables adds up to a constant, validating the notion that a rise in one trilemma variable should be traded-off with a drop of the weighted sum of the other two.
\end{abstract}

JEL Classification Nos.: F31, F36, F41, O24

Keywords: Impossible trinity; international reserves; financial liberalization; exchange rate regime.

Acknowledgements: The financial support of faculty research funds of the University of California, Santa Cruz, the University of Wisconsin, Madison, and Portland State University is gratefully acknowledged. We also thank Erica Clower and Lakin Garth for their excellent research assistance. We would like to thank Eduardo Borensztein, Eduardo Cavallo, Camilo Tovar, and the participants at the BIS-LACEA 2008 meeting for their useful comments and suggestions.

* Aizenman: Economics Department, University of California, Santa Cruz, Engineering 2, 401, Santa Cruz, CA 95064. Phone: (831) 459-2743. Email: jaizen@ucsc.edu.

** Chinn: Robert M. La Follette School of Public Affairs; and Department of Economics, University of Wisconsin, 1180 Observatory Drive, Madison, WI 53706. Email: mchinn@lafollette.wisc.edu

*** Ito: Department of Economics, Portland State University, 1721 SW Broadway, Portland, OR 97201. Tel/Fax: +1-503-725-3930/3945. Email: ito@pdx.edu 


\section{Introduction}

A fundamental contribution of the Mundell-Fleming framework is the impossible trinity, or the trilemma, which states that a country simultaneously may choose any two, but not all, of the following three goals: monetary independence, exchange rate stability and financial integration. The trilemma -- sometimes termed "the impossible trinity" -- is illustrated in Figure 1; each of the three sides - representing monetary independence, exchange rate stability, and financial integration - depicts a potentially desirable goal, yet it is not possible to be simultaneously on all three sides of the triangle. The top vertex - labeled "closed capital markets” - is associated with monetary policy autonomy and a fixed exchange rate regime, but not financial integration, the preferred choice of most developing countries in the mid to late 1980s. ${ }^{1}$

Over the last 20 years, most developing countries have opted for increasing financial integration. The trilemma implies that a country choosing this path must either forego exchange rate stability if it wishes to preserve a degree of monetary independence, or forego monetary independence if it wishes to preserve exchange rate stability.

The purpose of this paper is to outline a methodology that will allow us to easily and intuitively characterize and assess the choices countries have made with respect to the trilemma, during the post Bretton-Woods period. The first part of this paper introduces the "trilemma indexes," that measures the extent of achievement in each of the three policy goals pertaining to the trilemma, namely, monetary independence, exchange rate stability, and financial integration. These indexes allow us to trace the evolving configurations of the international financial architecture. Secondly, using these indexes, we explore positive aspects of the trilemma and examine how external shocks such as institutional changes in the international financial

\footnotetext{
${ }^{1}$ See Obstfeld, Shambaugh, and Taylor (2005) for further discussion and references dealing with the trilemma.
} 
architecture (e.g., the collapse of the Bretton Woods system) and large-scale financial crises (e.g., the Mexican debt crisis and the Asian financial crisis) have affected countries' preferences over the three trilemma policy goals. Lastly, we examine whether the constraints based on the trilemma are binding. That is, using a simple linear specification that links the three trilemma indexes, we test whether the linear combination of the three indexes adds up to a constant. If it is found to be true, that indicates that the notion that countries can only pursue two out of the three policy goals is true, and that a rise in one trilemma variable should be traded-off with a drop of the weighted sum of the other two.

We begin by observing that over the last two decades, a growing number of developing countries have opted for hybrid exchange rate regimes - e.g., managed float buffered by increasing accumulation of international reserves [IR henceforth]. Despite the proliferation of greater exchange rate flexibility, IR/GDP ratios increased dramatically, especially in the wake of the East Asian crises. Practically all the increase in IR/GDP holding has taken place in emerging market countries [see Figure 2]. The magnitude of the changes during recent years is staggering: global reserves increased from about USD 1 trillion to more than USD 5 trillion between 1990 and 2006.

The dramatic accumulation of international reserves has been uneven: while the IR/GDP ratio of industrial countries was relatively stable at approximately 4\%, the IR/GDP ratio of developing countries increased from about $5 \%$ to about $27 \%$. Today, about three quarters of the global international reserves are held by developing countries. Most of the accumulation has been in Asia, where reserves increased from about 5\% in 1980 to about 37\% in 2006 (32\% in Asia excluding China). The most dramatic changes occurred in China, increasing its IR/GDP ratio from about 1\% in 1980, to about 41\% in 2006 (and approaching 50\% by 2008). Empirical studies suggest several structural changes in the patterns of reserves hoarding (Cheung and Ito, 
2007; Obstfeld, et al. 2008). A drastic change occurred in the 1990s in terms of reserve management among developing countries. The IR/GDP ratios shifted upwards; the ratios increased dramatically immediately after the East Asian crisis of 1997-8, but subsided by 2000 . Another structural change took place in the early 2000s, mostly driven by an unprecedented increase in the accumulation of international reserves by China.

The globalization of financial markets is evident in the growing financial integration of all groups of countries. While the original framing of the trilemma was silent regarding the role of reserves, recent trends suggest that hoarding reserves may be closely related to changing patterns of the trilemma for developing countries. The earlier literature focused on the role of international reserves as a buffer stock critical to the management of an adjustable-peg or managed-floating exchange-rate regime. ${ }^{2}$ While useful, the buffer stock model has limited capacity to account for the recent development in international reserves hoarding - the greater flexibility of the exchange rates exhibited in recent decades should help reduce reserve accumulation, in contrast to the trends reported above.

The recent literature has focused on the adverse side effects of deeper financial integration of developing countries - the increased exposure to volatile short-term inflows of capital (dubbed "hot money"), subject to frequent sudden stops and reversals (see Calvo, 1998). The empirical evidence suggests that international reserves can reduce both the probability of a sudden stop and the depth of the resulting output collapse when the sudden stop occurs. ${ }^{3}$

Aizenman and Lee (2007) link the large increase in reserves holding to the deepening financial integration of developing countries and find evidence that international reserves hoarding serves as a means of self-insurance against exposure to sudden stops. In extensive empirical analysis of

\footnotetext{
${ }^{2}$ Accordingly, optimal reserves balance the macroeconomic adjustment costs incurred in the absence of reserves with the opportunity cost of holding reserves (Frenkel and Jovanovic, 1981).

${ }^{3}$ See Ben-Bassat and Gottlieb (1992), Rodrik and Velasco (1999), and Aizenman and Marion (2004) for papers viewing international reserves as output and consumption stabilizers.
} 
the shifting determinants of international reserve holdings for more than 100 economies over the 1975-2004 period, Cheung and Ito (2007) find that while trade openness is the only factor that is significant in most of the specifications and samples under consideration, its explanatory power has been declining over time. In contrast, the explanatory power of financial variables has been increasing over time.

The increasing importance of financial integration as a determinant for international reserves hoarding suggests a link between the changing configurations of the trilemma and the level of international reserves. Indeed, Obstfeld, et al. (2008) find that the size of domestic financial liabilities that could potentially be converted into foreign currency (M2), financial openness, the ability to access foreign currency through debt markets, and exchange rate policy are all significant predictors of international reserve stocks.

We begin by constructing an easy and intuitive way to summarize these trends, in the form of a "Diamond chart," where we add to the three trilemma dimensions - monetary independence, exchange rate stability and financial integration - a measure of international reserves hoarding (IR/GDP). Applying the methodology outlined in the next section, we construct for each country a vector of trilemma and IR configurations that measures each country’s monetary independence, exchange rate stability, international reserves and financial integration. These measures are normalized between zero and one. Each country’s configuration at a given instant is summarized by a 'generalized diamond,' whose four vertices measure monetary independence, exchange rate stability, IR/GDP, and financial integration.

A key message of the trilemma is instrument scarcity - policy makers face a tradeoff, where increasing one trilemma variable (such as higher financial integration) would induce a drop in the weighted average of the other two variables (lower exchange rate stability, or lower monetary independence, or a combination of the two). Yet, to our knowledge, the validity of this 
tradeoff among the three trilemma variables has not been tested properly. A possible concern is that the trilemma framework does not impose an exact functional restriction on the association between the three trilemma policy variables.

We close the paper by applying a regression analysis testing the validity of the simplest functional specification for the trilemma: whether the three trilemma policy goals are linearly related. For this purpose, we also examine and validate that the weighted sum of the three trilemma policy variables adds up to a constant (see Figure 7). This result confirms the notion that a rise in one trilemma variable should be traded-off with a drop of a linear weighted sum of the other two trilemma variables. The regression results also provide another diagnostic tool, allowing a simple description of the changing ranking among the three trilemma policy goals overtime.

Section 2 outlines the methodology for the construction of our "trilemma indexes" that measure the extent of achievement in the three policy goals. This section also presents summary statistics of the indexes and examines whether the indexes entail any structural breaks corresponding to major global economic events. Section 3 tests the validity of a linear specification of the trilemma indexes to examine whether the notion of the trilemma can be considered to be a trade-off and binding. Section 4 concludes the paper.

\section{Measures of the Trilemma Dimensions}

The empirical analysis of the tradeoffs being made requires measures of the policies. Unfortunately, there is a paucity of good measures; in this paper we remedy this deficiency by creating several policy metrics.

\subsection{Construction of the Trilemma Measures}




\section{Monetary Independence (MI)}

The extent of monetary independence is measured as the reciprocal of the annual correlation of the monthly interest rates between the home country and the base country. Money market rates are used. ${ }^{4}$

The index for the extent of monetary independence is defined as:

$$
M I=1-\frac{\operatorname{corr}\left(i_{i}, i_{j}\right)-(-1)}{1-(-1)}
$$

where $i$ refers to home countries and $j$ to the base country. By construction, the maximum and minimum values are 1 and 0 , respectively. Higher values of the index mean more monetary policy independence.

Here, the base country is defined as the country that a home country's monetary policy is most closely linked with, as defined in Shambaugh (2004). The base countries are Australia, Belgium, France, Germany, India, Malaysia, South Africa, the U.K., and the U.S. For the countries and years for which Shambaugh's data are available, the base countries from his work are used, and for the others, the base countries are assigned based on IMF's Annual Report on Exchange Arrangements and Exchange Restrictions (AREAER) and CIA Factbook.

\section{Exchange Rate Stability (ERS)}

To measure exchange rate stability, annual standard deviations of the monthly exchange rate between the home country and the base country are calculated and included in the following formula to normalize the index between zero and one:

\footnotetext{
${ }^{4}$ The data are extracted from the IMF's International Financial Statistics (60B..ZF...). For the countries whose money market rates are unavailable or extremely limited, the money market data are supplemented by those from the Bloomberg terminal and also by the deposit rates series from IFS.
} 


$$
E R S=\frac{1}{1+\frac{s t d e v(\text { exch_rate })}{\left|d \log E_{t} / d t\right|+0.01}}
$$

$\left|d \log E_{t} / d t\right|$ is the absolute value of the year-on-year depreciation rate using the exchange rate as of December of the year. Higher values of this index indicate more stable movement of the exchange rate against the currency of the base country.

\section{Financial Openness/Integration (KAOPEN)}

Without question, it is extremely difficult to measure the extent of capital account controls. ${ }^{5}$ Although many measures exist to describe the extent and intensity of capital account controls, it is generally agreed that such measures fail to capture fully the complexity of realworld capital controls. Nonetheless, for the measure of financial openness, we use the index of capital account openness, or KAOPEN, developed by Chinn and Ito $(2006,2008)$. KAOPEN is based on information regarding restrictions in the IMF's Annual Report on Exchange Arrangements and Exchange Restrictions (AREAER). Specifically, KAOPEN is the first standardized principal component of the variables that indicate the presence of multiple exchange rates, restrictions on current account transactions, on capital account transactions, and the requirement of the surrender of export proceeds. Since KAOPEN is based upon reported restrictions, it is necessarily a de jure index of capital account openness as opposed to de facto measures such as those in Lane and Milesi-Ferretti (2006). The choice of a de jure measure of capital account openness is driven by the motivation to identify the policy intentions of the

\footnotetext{
${ }^{5}$ See Chinn and Ito (2008), Edison and Warnock (2001), Edwards (2001), Edison et al. (2002), and Kose et al. (2006) for discussions and comparisons of various measures on capital restrictions.

${ }^{7}$ De jure measures of financial openness also face their own limitations. As Edwards (1999) discusses, it is often the case that the private sector circumvents capital account restrictions, nullifying the expected effect of regulatory capital controls. Also, IMF-based variables are too aggregated to capture the subtleties of actual capital controls, that is, the direction of capital flows (i.e., inflows or outflows) as well as the type of financial transactions targeted.
} 
countries; de facto measures incorporate both macroeconomic shocks as well as policy decisions regarding capital controls. ${ }^{7}$

The Chinn-Ito index is normalized so as to range between zero and one. Higher values of this index indicate that a country is more open to cross-border capital transactions. The index is available for 171 countries for the period of 1970 through $2006 .{ }^{8}$ We exclude the United States from the statistical analysis. The Appendix presents data availability in more details.+

\subsection{Tracking the Indexes}

\section{Variations across Country Groupings}

Comparing theses indexes provides some interesting insights into how the international financial architecture has evolved over time. For this purpose, the "diamond charts” are most useful. Figure 3 summarizes the trends for industrialized countries, those excluding the 12 euro countries, emerging market countries, and non-emerging market developing countries. ${ }^{9}$ It shows that industrial countries have moved toward greater financial liberalization over the years. One can also see that industrialized countries have also stabilized exchange rates, but this result is mainly driven by the countries that have adopted the euro. Once the euro countries are removed, the remaining industrialized countries do not appear to have lost monetary independence. The figure also highlights the fact that developing countries have moved toward greater exchange rate flexibility and deeper financial integration. Both trends are more pronounced for the emerging market countries than for non-emerging market developing countries. In addition, the emerging market group of countries is distinct in terms of experiencing a rapid rise in the level of

\footnotetext{
${ }^{8}$ The original dataset covers more than 131 countries, but data availability is uneven among the three indexes. $M I$ is available for 171 countries; ERS for 179; and KAOPEN for 177. Both MI and ERS start in 1960 whereas KAOPEN in 1970. For the data availability of the trilemma indexes, refer to Appendix.

${ }^{9}$ The emerging market countries are defined as the countries classified as either emerging or frontier during the period of 1980-1997 by the International Finance Corporation, plus Hong Kong and Singapore.
} 
international reserves accumulation. While non-emerging market developing countries also experienced some increase in their international reserves, the change in their reserves has been much more moderate. In contrast, industrialized countries have lowered their holdings of reserves.

Figure 4 compares developing countries across different geographical groups. Developing countries in both Asia and Latin America (LATAM) have moved toward exchange rate flexibility, but LATAM countries have rapidly increased financial openness while Asian counterparts haven not. Asian emerging market economies have moved further toward financial openness on a level comparable with LATAM emerging market countries, yet one key difference between the two groups is that the former holds much more international reserves than the latter. Sub-Saharan African countries have also moved toward floating exchange rate and financial liberalization compared to the 1980s, but the extent of the change is much less marked.

\section{Patterns in a Balanced Panel}

Figure 5 again presents the development of trilemma indexes for different subsamples while focusing on the time dimension of the development of the indexes, but also restricts the entire sample to include only the countries for which all three indexes are available for the entire time period. By balancing the dataset, the number of countries included in the sample declines to 50 countries, of which 32 are developing countries (18 of which are in turn emerging market countries). Each panel presents the full sample (i.e., cross-country) average of the trilemma index of concern and also its one-standard deviation band.

There is a striking differences between industrialized and developing countries. The topleft panel shows that, between the late 1970s and the late 1980s, the levels of monetary independence in industrialized and developing countries were close together. However, since the 
early 1990s, these two groups have been diverging from each other. While developing countries have been hovering around intermediate levels of monetary independence and slightly deviating from the cross-country average, industrialized countries have steadily become much less independent in terms of monetary policy, and moved farther away from the cross-country average, reflecting the efforts made by the euro member countries. ${ }^{10}$ In the case of the exchange rate stability index, industrialized countries experienced a constant level of exchange rate stability until the end of the 1990s, while developing countries had been on a general trend toward more exchange rate flexibility since the mid-1970s. After the introduction of the euro in 1999, industrialized countries drastically increased the level of exchange rate stability while developing countries continued to remain around the mid-level of exchange rate flexibility. ${ }^{11}$ Not surprisingly, industrialized countries have achieved higher levels of financial openness throughout the period. The acceleration of financial openness in the mid-1990s remained significantly high compared to the cross-country average of both the full sample and LDC subsample. On the other hand, developing countries also accelerated the move to financial openness in the early 1990s, but only after some retrenchment during the 1980s. Overall, trends in the LDC countries have parallelled the global trend of financial liberalization throughout the sample period; however the gap with the industrialized countries has been moderately rising in the last decade.

The difference between emerging market countries and non-emerging market, developing countries (shown in the bottom row of Figure 5) is smaller than that between IDC and LDC subsamples. However, the divergence in terms of monetary independence and financial openness

\footnotetext{
${ }^{10}$ When the euro countries are removed from the IDC sample, the extent of the divergence from the average becomes less marked although there is still a tendency among the non-euro countries to move toward lower levels of monetary independence.

${ }^{11}$ The trend of the non-euro industrialized countries after the late 1990s more or less traces that of developing countries though it is a little more volatile.
} 
has been noticeable since the mid-1990s. While non-EMG countries have retained relatively constant levels of monetary independence, EMG countries have become less monetary independent. EMG countries have also become more financially open compared with non-EMG countries.

Table 6 shows the development paths of these indexes altogether, making the differences between IDCs and LDCs appear more distinctly. For the industrialized countries, it is clear that after the late 1990s, financial openness and exchange rate stability are the most pursued macroeconomic policies, reflecting the introduction of the euro in $1999 .{ }^{12}$ The group of developing countries presents a very different picture. Up to 1990, exchange rate stability was the most pervasive policy among the three, though it has been on a declining trend since the early 1970s. During the 1990s, the level of monetary independence went up on average while more countries adopted floating exchange rates and liberalized financial markets. Interestingly, all three variables have been converged since 2000. This result suggests that developing countries have converged towards managed exchange rate flexibility, and also is consistent with the sizable increase in international reserves which many have viewed as critical to sustaining monetary independence in a time of growing financial integration. Willett (2003) has called this compulsion by countries with an intermediate level of exchange rate fixity to hoard reserves the "unstable middle” hypothesis (as opposed to the “disappearing middle” view).

\subsection{Identifying Structural Breaks}

To shed more light on the evolution of the index values, we investigate whether major international economic events have been associated with structural breaks in the index series. We

\footnotetext{
${ }^{12}$ If the euro countries are removed from the sample (not reported), financial openness evolves similarly to the IDC group that includes the euro countries, but exchange rate stability hovers around the line for monetary independence, though at a bit higher levels, after the early 1990s. The difference between exchange rate stability and monetary independence has been slightly diverging after the end of the 1990s.
} 
conjecture that major events - such as the breakdown of the Bretton Woods system in 1973, the Mexican debt crisis of 1982 (indicating the beginning of 1980’s debt crises of developing countries), and the Asian Crisis of 1997-98 (the onset of sudden stop crises affecting highperforming Asian economies (HPAEs), Russia and other emerging countries) - may have affected economies in such significant ways that they opted to alter their policy choices.

We identify the years of 1973, 1982, 1997-98, and 2001 as candidate structural breaks, and test the equality of the group mean of the indexes over the candidate break points for each of the subsample groups. ${ }^{13}$ The results are reported in Table 1 (a). The first and second columns of the top panel indicate that after the breakdown of the Bretton Woods system, the mean of the exchange rate stability index for the industrialized country group fell statistically significantly from 0.55 to 0.45 , while the mean of financial openness slightly increase from 0.44 to 0.47 . Interestingly, non-emerging market developing countries significantly increased the level of fixity of their exchange rates (from 0.52 to 0.82 ) over the same time period while they became less monetarily independent and more financially open. However, the movement toward more fixed exchanged rate is not observed among emerging market economies. In fact, these economies moved more toward floating exchange rates.

Even after the Mexican debt crisis, industrialized countries continued to increase exchange rate flexibility and financial openness, while holding constant the level of monetary independence. In contrast, the debt crisis led all developing countries to pursue further exchange rate flexibility, most likely reflecting the fact that crisis countries could not sustain fixed exchange rate arrangements. However, these countries also simultaneously pursued more

\footnotetext{
${ }^{13}$ The data for the candidate structural break years are not included in the group means either for pre- or poststructural break years. For the Asian crisis, we assume the years of 1997 and 1998 are the break years and therefore remove observations for these two years.
} 
monetary independence. Interestingly, non-emerging market countries tightened capital controls as a result of the debt crisis while emerging market countries did not alter their stance.

The Asian crisis also appears to be a significant event in the evolution of the trilemma indexes. The level of industrialized countries’ monetary independence dropped significantly while their exchange rates became much more stable and their efforts of capital account liberalization continued, all reflecting the European countries' movement toward economic and monetary union. Non-emerging market developing countries on the other hand started pursuing financial integration and continued to pursue more flexible exchange rates and more independent monetary policy. Emerging market countries on the other hand also started liberalizing financial markets much further, but lost monetary independence while pursuing flexible exchange rates.

Several other major events are candidates for inducing structural breaks identified. For example, anecdotal accounts date globalization at the beginning of the 1990s, leading many developing countries began to liberalize financial markets. Also, China’s entry to the World Trade Organization in 2001 was, in retrospect, the beginning of the country's rise as the world's factory. Because the effect of these events may be conflated with that of the Asian crisis we also test whether the years of 1990 and 2001 might be structural breaks.

The results are reported in Table 1 (b); the first two columns show the results of the mean equality test for the trilemma indexes with the year of 1990 as the candidate structural break whereas the last two columns report those with the year of 2001 as the structural break. The top panel shows that for industrialized countries, 1990 can be a structural break for all three indexes. However, when we compare the statistical magnitude of the change in the index for monetary independence across different candidate structural breaks (i.e., compare the t-statistics for monetary independence in column 4 of Table 1 (a), in column 2 of Table 1 (b), and in column 4 of Table 1 (b)), the mean equality test is most strongly rejected for the no structural break of 
1997-98 hypothesis. We obtain the same result for exchange rate stability though for financial openness, the structural break of 1990 rejects the null hypothesis the most significantly. ${ }^{14}$

We apply the same test to the samples of non-emerging developing countries and emerging market countries. For the group of non-emerging market developing countries, the structural break of 1990 is the most significant for all indexes. For emerging market countries, however, the most significant structural break is found to have occurred in 2001 for monetary independence, in 1990 for exchange rate stability, and in 1997-98 for financial openness.

Lastly, we compare the t-statistics across different structural breaks for each of the indexes and subsamples. Given that the balanced dataset is used in this exercise, the largest tstatistic should indicate the most significant structural break for the series. For example, industrial countries' monetary independence and exchange rate stability series have the largest tstatistics when the structural break of 1997-98 is tested for. ${ }^{15}$ For financial openness, however, the year of 1990 is found to be the most significant structural break. The results for other variables and subsamples are shown in Table 1 (c). For non-emerging LDC and EMG countries, structural breaks for monetary independence and exchange rate stability are found to have occurred in 2001 and 1982, respectively. While the breakdown of the Bretton Woods system was the most significant event for non-emerging LDC countries in terms of the countries’ financial liberalization policy, the Asian crisis was the most significant event for emerging market countries.

\footnotetext{
${ }^{14}$ The finding that both monetary independence and exchange rate stability entail structural breaks around the Asian crisis can be driven merely by the countries that adopted the euro in 1999. We repeat the same exercise using the industrial countries sample without the euro countries, and find that the structural breaks for monetary independence and financial opens remain the same as in the full IDC sample (1997-98 and 1990, respectively), but that the exchange rate stability series is found to have a structural break in 2001. Also, the change in the exchange rate stability series is negative (i.e., further exchange rate flexibility) in both 1990 and 2001.

${ }^{15}$ When the sample is restricted to non-euro IDCs, the most significant structural break is found to be 2001 for exchange rate stability while those for monetary independence and financial openness are unchanged.
} 


\section{$3 \quad$ Linear Relationships of the Trilemma Indexes}

While the preceding analyses are quite useful for tracing out the evolution of international macroeconomic policy orientation, we have not demonstrated whether these three macroeconomic policy goals are "binding" in the sense of the impossible trinity. That is, it is important for us to provide evidence that countries have faced the trade-offs based on the trilemma. A challenge facing a full test of the trilemma tradeoff is that the trilemma framework does not impose any obvious functional form on the nature of the tradeoffs between the three trilemma variables. To illustrate this concern, we must note that the instrument scarcity association with the trilemma implies that increasing one trilemma variable, say higher financial integration, should induce lower exchange rate stability, or lower monetary independence, or a combination of these two policy adjustments. ${ }^{16}$ Hence, we test the validity of the simplest possible trilemma specification - a linear tradeoff. Specifically, we test whether the weighted sum of the three trilemma policy variables equals a constant. This reduces to examining the goodness of fit of this linear regression:

$1=a_{j} M I_{i, t}+b_{j} E R S_{i, t}+c_{j} K A O P E N_{i, t}+\varepsilon_{t} \quad$ where $j$ can be either IDC, ERM, or LDC.

Because we have shown that different subsample groups of countries have experienced different development paths, we allow the coefficients on all the variables to vary across different groups of countries - industrialized countries, the countries that have been in the European Exchange Rate Mechanism (ERM), and developing countries - by allowing for interactions between the explanatory variables and the dummies for these subsamples. ${ }^{17}$ The regression is run for the full

\footnotetext{
${ }^{16}$ More generally, increasing of one Trilemma variable should induce a drop of the second Trilemma variable, or a drop in the third Trilemma variable, or a combination of the two.

${ }^{17}$ The dummy for ERM countries is assigned for the countries and years that corresponds to participation in the ERM (i.e., Belgium, Denmark, Germany, France, Ireland, and Italy from 1979 on, Spain from 1989, U.K. only for 1990-91, Portugal from 1992, Austria from 1995, Finland from 1996, and Greece from 1999).
} 
sample period as well as the subsample periods identified in the preceding subsection. The results are reported in Table 2.

The rationale behind this exercise is that policy makers of an economy must choose a weighted average of the three policies in order to achieve a best combination of the two. Hence, if we can find the goodness of fit for the above regression model is high, it would suggest a linear specification is rich enough to explain the trade off among the three policy dimensions. In other words, the lower the goodness of fit, the weaker the support for the existence of the tradeoff, suggesting either that the theory of the trilemma is wrong, or that the relationship is nonlinear.

Secondly, the estimated coefficients in the above regression model should give us some approximate estimates of the weights countries put on the three policy goals. However, the estimated coefficients alone will not provide sufficient information about "how much of" the policy choice countries have actually implemented. Hence, looking into the predictions using the estimated coefficients and the actual values for the variables (such as $\hat{a} M I, \hat{b} E R S$, and ĉKAOPEN ) will be more informative.

Thirdly, by comparing the predicted values based on the above regression, i.e., $\hat{a} M I+\hat{b} E R S+\hat{c} K A O P E N$, over a time horizon, we can get some inferences about how "binding” the trilemma is. If the trilemma is found to be linear constraint, the predicted values should hover around the value of 1 , and the prediction errors should indicate how much of the three policy choices have been "not fully used" or to what extent the trilemma is "not binding."

Table 2 presents the regression results. The results from the regression with the full sample data are reported in the first column, and the others for different subsample periods are in the following columns. First of all, the adjusted R-squared for the full sample model as well as for the subsample periods is found to be above $94 \%$, which indicates that the three policy goals 
are linearly related to each other, that is, countries face the trade-off among the three policy options. Across different time periods, the estimated coefficients vary, suggesting that the nature of the tradeoffs varies, either because of changes in the governments' objective functions, or the changing nature of the economies.

Figure 7 illustrates the goodness of fit from a different angle. In the top panels, the solid lines show the means of the predicted values (i.e., $\hat{a} M I+\hat{b} E R S+\hat{c} K A O P E N$ ) based on the full sample model in the first column of Table 2 for the groups of industrial countries (left) and developing countries (right). ${ }^{18}$ To incorporate the time variation of the predictions, the subsample mean of the prediction values as well as their 95\% confidence intervals (that are shown as the shaded areas) are calculated using five-year rolling windows. ${ }^{19}$ The panels also display the rolling means of the predictions using the coefficients and actual values of only two of the three trilemma terms $-\hat{a} M I+\hat{b} E R S$ (brown line with diamond nodes), $\hat{a} M I+\hat{c} K A O P E N$ (green line with circles), $\hat{b} E R S+\hat{c} K A O P E N$ (orange line with “x”).

From these panels of figures, we can see first that the predicted values based on the model hover around the value of one closely for both subsamples. For the group of industrial countries, the prediction average is statistically below the value of one in the late 1970s, the early 1980s, and the late 1980s. However, since the beginning of the 1990s, one cannot reject the null hypothesis that the mean of the prediction values is one, indicating that the trilemma is "binding"

\footnotetext{
${ }^{18}$ For this exercise, predictions also incorporate the interactions with the dummy variables shown in Table 2.

${ }^{19}$ Both the mean and the standard errors of the predicted values are calculated using the rolling five-year windows. The formula for the mean and the standard errors can be shown as $\bar{X}_{t \mid t-4}=\sum_{t}^{t-4} \sum_{i=1}^{n} \hat{x}_{i t} / n \times 5$ and $S E(\hat{x})=\sqrt{\frac{\sum_{t}^{t-4} \sum_{i=1}^{n}\left(\hat{x}_{i_{t}}-\bar{x}_{t \mid t-4}\right)^{2}}{n \times 5-1}} / \sqrt{n \times 5}$, respectively, where $n$ refers to the number of countries in a subsample (i.e., IDC and LDC), $\hat{x}_{i t}$ to the prediction values, and $\bar{x}_{t \mid t-4}$ to the mean of $\hat{x}_{i t}$ in the rolling five-year window. Because of the use of rolling five-year windows, the lines in the figures only start in 1974.
} 
for industrialized countries since then. For developing countries, the model is under-predicting from the end of the 1970s through the beginning of the 1990s. However, unlike the IDC group, the mean of the predictions has become statistically smaller than one since 2000. At the very least, the mean of the predictions never gets above the value of one in statistical sense, implying that, despite some years when the trilemma is not binding, the three macroeconomic policies are linearly related with each other. ${ }^{20}$

The top panels also show that, among industrialized countries, the policy combination of increasing exchange rate stability and more financial openness became increasingly prevalent after the beginning of the 1990s whereas that of monetary independence and exchange rate stability has been consistently declining over the years. Among developing countries, the policy combination of exchange rate stability and financial openness has been the least prevalent over the sample period, most probably reflecting the bitter experiences of currency crises. The policy combinations of monetary independence and financial openness or that of monetary independence and exchange rate stability has been quite dominant, but that is mainly because of the dominant preference for monetary independence through the time period.

In the lower panels, we can observe the contributions of each policy orientation (i.e., $\hat{a} M I, \hat{b} E R S$, and $\hat{c} K A O P E N$ ) for the IDC and LDC groups. ${ }^{21}$ These panels present a picture consistent with Figures 5 and 6. While less developed countries maintained high, though fluctuating, levels of monetary independence as well as a low, but constant level of exchange rate stability, these countries gradually increased the level of capital account openness starting in

\footnotetext{
${ }^{20}$ One may question the uniqueness of this regression exercise by pointing at the left-hand side variable being an identity scalar. As a robustness check, we ran a regression of $M I_{i, t}$ on $E R S_{i, t}$ and $K A O P E N_{i, t}$, recovered the estimated coefficients for $a_{j}, b_{j}$, and $c_{j}$. in equation (1), and recreated panels of figures comparable to those in Figure 7 . These alternative figures appeared to be very much comparable to Figure 7 and therefore confirmed our conclusions about the linearity of the trilemma indexes as well as the development of the subsample mean of prediction values based on equation (1).

${ }^{21}$ They are again the means based on five-year rolling windows.
} 
the 1990s. However, this effort of achieving three policy goals at once can be done only when the countries accumulate high levels of international reserves that allow them to intervene in foreign exchange markets, consistent with the fact that many developing countries increasing international reserves in the aftermath of the Asian crisis of 1997-98. However, as the concept of the trilemma predicts, this sort of environment must involve a rise in the costs of sterilized intervention especially when the actual volume of cross-border transactions of financial assets increase and when there is no reversal in the three policies. ${ }^{22}$ This seems to explain the drop in the level of monetary independence after 2000 for this group of countries. ${ }^{23}$

The experience of the industrialized countries casts a stark contrast. Although monetary independence was also IDC's top priority until the 1990s, it yielded to financial integration in the early 1990s when many industrialized countries liberalized their financial markets. The efforts of financial liberalization correspond to declines in the level of monetary independence, which persistently kept falling and became the lowest priority in the 2000s. Such changes in the relative weights of the three policy goals do not require the countries to accumulate international reserves as was the case with developing countries.

We also repeat the exercise using the regression models for each of the subsample period (excluding the break years). The results (not reported) are qualitatively the same as in Figure 7. Also, using the predictions based on the subsample-based models, we test to see if there are any structural breaks in the predicted values in the same way as in the previous subsection. Interestingly, we find that for both IDC and LDC groups, the year of 1990 is found to be the most significant structural break. As far as the test results are concerned, the year of 1990, or the

\footnotetext{
${ }^{22}$ Refer to Aizenman and Glick (2008) and Glick and Hutchison (2008) for more analysis on the limit of sterilized intervention.

${ }^{23}$ When this exercise is repeated for both the emerging market country (EMG) group and the non-emerging market developing country group (Non-EMG LDC), the results remain about the same, only except for that the financial liberalization is more evident and the drop in the level of monetary independence is larger for the EMG group.
} 
starting year of waves of globalization, appears to be the most significant event that affects the international financial architecture.

\section{Concluding Remarks}

In this paper, we have described a methodology to trace the changing patterns in the configurations the trilemma has manifested. Our methodology reveals the striking differences in the choices that industrialized and developing countries have made over the 1970-2006 period. Recent trends suggest that among developing countries, the three dimensions of the trilemma configurations -- monetary independence, exchange rate stability, and financial openness -- are converging towards a "middle ground” with managed exchange rate flexibility, underpinned by sizable holdings of international reserves, and intermediate levels of monetary independence and financial integration. Industrialized countries, on the other hand, have been experiencing divergence of the three dimensions of the trilemma and moved toward the combination of high exchange rate stability and financial openness and low monetary independence (most clearly exemplified by the advent of the euro).

The system has evolved over time, it would be a mistake to think of the process as being smooth and continuous. Rather, there have been a number of discrete, structural breaks associated with significant events: the collapse of the Bretton Woods system, the debt crisis of 1982, and the Asian crisis of 1997-98. In addition, accelerating globalization and the rise of China have also affected policy arrangements substantially.

We also tested whether the three macroeconomic policy goals are "binding" in the context of the impossible trinity, by estimating the nature of the trade-offs faced by countries. Because there is no specific functional form of the trade-offs or the linkage of these three policy 
goals, we estimated the simplest linear specification for the three trilemma indexes and examined whether the weighted sum of the three trilemma policy variables equals a constant. Our results confirmed that countries do face a binding trilemma. That is, a change in one of the trilemma variables induces a change with the opposite sign in the weighted average of the other two variables. In that sense, we have provided substantial content to the hypothesis of the 'impossible trinity”. 


\section{References}

Aizenman, J. and R. Glick. 2008. "Sterilization, Monetary Policy, and Global Financial Integration,” mimeo, University of California, Santa Cruz. Forthcoming in Review of International Economics.

Aizenman, J. and Marion, N. 2004. "International reserves holdings with sovereign risk and costly tax collection.” Economic Journal 114, pp. 569-91.

Aizenman, J. and Lee, J. 2007. "International reserves: precautionary versus mercantilist views, theory and evidence,” Open Economies Review, 2007, 18 (2), pp. 191-214.

Ben-Bassat A. and Gottlieb, D. 1992. "Optimal international reserves and sovereign risk.” Journal of International Economics 33, pp. 345-62.

Calvo, G. 1998. "Capital Flows and Capital-market Crises: The Simple Economics of Sudden Stops.” Journal of Applied Economics 1: 35-54.

Caballero, R.J., and A. Krishnamurthy, 2001, "International and Domestic Collateral Constraints in a Model of Emerging Market Crises,” Journal of Monetary Economics, Vol. 48, pp. 513-48.

Cavallo, E.A., and J.A. Frankel. 2004. "Does Openness to Trade Make Countries More Vulnerable to Sudden Stops, or Less?” NBER Working Paper 10957. Cambridge, United States: National Bureau of Economic Research.

Cheung, Y-W and H. Ito. 2007. "Cross-sectional analysis on the determinants of international reserves accumulation,” mimeo, University of California, Santa Cruz.

Chinn, M. D. and H. Ito. 2008 “A New Measure of Financial Openness.” Journal of Comparative Policy Analysis, Volume 10, Issue 3 (September), p. 309 - 322.

Chinn, M. D. and H. Ito, 2006. "What Matters for Financial Development? Capital Controls, Institutions, and Interactions,” Journal of Development Economics, Volume 81, Issue 1, Pages 163-192 (October).

Edison, Hali J., M. W. Klein, L. Ricci, and T. Sløk, 2002. “Capital Account Liberalization and Economic Performance: A Review of the Literature,” IMF Working Paper (May).

Edison, Hali J. and F. E. Warnock, 2001. "A simple measure of the intensity of capital controls," International Finance Discussion Paper \#708 (Washington, D.C.: Board of Governors of the Federal Reserve System, September).

Edwards, S., 2001. “Capital Mobility and Economic Performance: Are Emerging Economies Different?” NBER Working Paper No. 8076.

Frenkel, J. and Jovanovic, B. 1981. “Optimal international reserves: a stochastic framework. Economic Journal 91, 507-14. 
Kose, M. A., E. Prasad, K. Rogoff, and S. J. Wei, 2006, “Financial Globalization: A Reappraisal,” IMF Working Paper, WP/06/189.

Lane, P. R. and Milesi-Ferretti, G. M. 2006. “The External Wealth of Nations Mark II: Revised and Extended Estimates of Foreign Assets and Liabilities, 1970-2004,” IMF Working Paper 06/69.

Obstfeld, M., J. C. Shambaugh, and A. M. Taylor, 2008. "Financial Stability, The Trilemma, and International Reserves.” NBER Working Paper 14217 (August).

Obstfeld, M., J. C. Shambaugh, and A. M. Taylor, 2005. "The Trilemma in History: Tradeoffs among Exchange Rates, Monetary Policies, and Capital Mobility." Review of Economics and Statistics 87 (August): 423-38.

Rodrik, D., and A. Velasco. 1999. "Short-Term Capital Flows." NBER Working Paper No. 7364. Cambridge, MA : National Bureau of Economic Research.

Shambaugh, Jay C. 2004. “The Effects of Fixed Exchange Rates on Monetary Policy.” Quarterly Journal of Economics 119 (February): 301-52.

Willett, T. 2003. “Fear of Floating Need Not Imply Fixed Exchange Rates,” Open Economies Review 14, 77 - 91. 


\section{Appendix: Data Availability of the Trilemma measures}

\begin{tabular}{|c|c|c|c|c|c|c|c|c|c|}
\hline \multirow[b]{2}{*}{1} & \multirow[t]{2}{*}{$\begin{array}{c}\begin{array}{c}\text { Country } \\
\text { code } \\
\text { (cn) }\end{array} \\
512\end{array}$} & \multirow[t]{2}{*}{$\begin{array}{l}\text { Country Name } \\
\text { Afghanistan (C) }\end{array}$} & \multirow[t]{2}{*}{$\begin{array}{l}\text { Base Country } \\
\text { U.S. }\end{array}$} & \multicolumn{2}{|c|}{$\begin{array}{c}\text { Monetary } \\
\text { Independence } \\
\text { (MI) } \\
\text { (171) }\end{array}$} & \multicolumn{2}{|c|}{$\begin{array}{c}\text { Exchange rate } \\
\text { stability } \\
\text { (ERS) } \\
(179)\end{array}$} & \multicolumn{2}{|c|}{$\begin{array}{c}\text { KA Openness } \\
\text { (KAOPEN) } \\
(177)\end{array}$} \\
\hline & & & & - & - & 1961 & 2005 & 1970 & 2004 \\
\hline 2 & 914 & Albania (C) & U.S. & 1992 & 2006 & 1993 & 2006 & 1996 & 2006 \\
\hline 3 & 612 & Algeria (C) & France & 1974 & 2006 & 1961 & 2006 & 1970 & 2006 \\
\hline 4 & 614 & Angola (C) & U.S. & 1995 & 2006 & 1961 & 2006 & 1993 & 2006 \\
\hline 5 & 311 & Antigua and Barbuda & U.S. & 1981 & 2006 & 1961 & 2006 & 1985 & 2006 \\
\hline 6 & 213 & Argentina $(E)(C)$ & U.S. & 1977 & 2006 & 1961 & 2006 & 1970 & 2006 \\
\hline 7 & 911 & Armenia & U.S. & 1995 & 2006 & 1993 & 2006 & 1996 & 2006 \\
\hline 8 & 314 & Aruba & U.S. & 1986 & 2006 & 1987 & 2006 & 1992 & 2006 \\
\hline 9 & 193 & Australia & U.S. & 1969 & 2006 & 1961 & 2006 & 1970 & 2006 \\
\hline 10 & 122 & Austria & Germany & 1960 & 2006 & 1961 & 2006 & 1970 & 2006 \\
\hline 11 & 912 & Azerbaijan & U.S. & 1993 & 2006 & 1993 & 2006 & 2000 & 2006 \\
\hline 12 & 313 & Bahamas, The & U.S. & 1970 & 2006 & 1961 & 2006 & 1977 & 2006 \\
\hline 13 & 419 & Bahrain (C) & U.S. & 1975 & 2006 & 1967 & 2006 & 1976 & 2006 \\
\hline 14 & 513 & Bangladesh (E) & U.S. & 1972 & 2006 & 1972 & 2006 & 1976 & 2006 \\
\hline 15 & 316 & Barbados & 1960-74 U.K.; 1975-U.S. & 1967 & 2006 & 1961 & 2006 & 1974 & 2006 \\
\hline 16 & 913 & Belarus & U.S. & 1993 & 2006 & 1993 & 2006 & 1996 & 2006 \\
\hline 17 & 124 & Belgium & Germany & 1960 & 2006 & 1961 & 2006 & 1970 & 2006 \\
\hline 18 & 339 & Belize & U.S. & 1979 & 2006 & 1961 & 2006 & 1985 & 2006 \\
\hline 19 & 638 & Benin & France & 1964 & 2006 & 1961 & 2006 & 1970 & 2006 \\
\hline 20 & 514 & Bhutan & Rupee & 1982 & 2006 & 1961 & 2006 & 1985 & 2006 \\
\hline 21 & 218 & Bolivia (C) & U.S. & 1960 & 2006 & 1961 & 2006 & 1970 & 2006 \\
\hline 22 & 616 & Botswana (E) (C) & South Africa & 1976 & 2006 & 1961 & 2006 & 1972 & 2006 \\
\hline 23 & 223 & Brazil (E) & U.S. & 1964 & 2006 & 1965 & 2006 & 1970 & 2006 \\
\hline 24 & 918 & Bulgaria (E) & Germany & 1991 & 2006 & 1961 & 2006 & 1996 & 2006 \\
\hline 25 & 748 & Burkina Faso & France & 1964 & 2006 & 1961 & 2006 & 1970 & 2006 \\
\hline 26 & 618 & Burundi (C) & 1960-70 Belgium; 1971-U.S. & 1977 & 2006 & 1961 & 2006 & 1970 & 2006 \\
\hline 27 & 662 & Cote d'Ivoire (E) (C) & France & 1964 & 2006 & 1961 & 2006 & 1970 & 2006 \\
\hline 28 & 522 & Cambodia & U.S. & 1994 & 2006 & 1961 & 2006 & 1973 & 2006 \\
\hline 29 & 622 & Cameroon & France & 1968 & 2006 & 1961 & 2006 & 1970 & 2006 \\
\hline 30 & 156 & Canada & U.S. & 1960 & 2006 & 1961 & 2006 & 1970 & 2006 \\
\hline 31 & 624 & Cape Verde & Germany & 1985 & 2006 & 1961 & 2006 & 1982 & 2006 \\
\hline 32 & 626 & Central African Rep. & France & 1968 & 2006 & 1961 & 2006 & 1970 & 2006 \\
\hline 33 & 628 & Chad (C) & France & 1968 & 2006 & 1961 & 2006 & 1970 & 2006 \\
\hline 34 & 228 & Chile (E) (C) & U.S. & 1977 & 2006 & 1961 & 2006 & 1970 & 2006 \\
\hline 35 & 924 & China $(E)$ & U.S. & 1980 & 2006 & 1961 & 2006 & 1970 & 2006 \\
\hline 36 & 233 & Colombia (E) & U.S. & 1964 & 2006 & 1961 & 2006 & 1970 & 2006 \\
\hline 37 & 632 & Comoros & France & 1983 & 2006 & 1961 & 2006 & 1981 & 2006 \\
\hline 38 & 636 & Congo, Dem. Rep. (C) & U.S. & 1982 & 2003 & 1961 & 2006 & 1970 & 2000 \\
\hline 39 & 634 & Congo, Rep. (C) & France & 1968 & 2006 & 1961 & 2006 & 1970 & 2006 \\
\hline 40 & 238 & Costa Rica & U.S. & 1964 & 2006 & 1961 & 2006 & 1970 & 2006 \\
\hline 41 & 960 & Croatia & Germany & 1992 & 2006 & 1993 & 2006 & 1998 & 2006 \\
\hline 42 & 423 & Cyprus & Germany & 1969 & 2006 & 1961 & 2006 & 1970 & 2006 \\
\hline 43 & 935 & Czech Republic (E) & Germany & 1993 & 2006 & 1994 & 2006 & 1998 & 2006 \\
\hline 44 & 128 & Denmark & Germany & 1960 & 2006 & 1961 & 2006 & 1970 & 2006 \\
\hline 45 & 611 & Diibouti & U.S. & 1996 & 2006 & 1961 & 2006 & 1982 & 2006 \\
\hline 46 & 321 & Dominica & U.S. & 1981 & 2006 & 1961 & 2006 & 1982 & 2006 \\
\hline 47 & 243 & Dominican Republic & U.S. & 1995 & 2006 & 1961 & 2006 & 1970 & 2006 \\
\hline 48 & 248 & Ecuador (E) & U.S. & 1970 & 2006 & 1961 & 2006 & 1970 & 2006 \\
\hline 49 & 469 & Egypt, Arab Rep. (E) & U.S. & 1964 & 2006 & 1961 & 2006 & 1970 & 2006 \\
\hline 50 & 253 & El Salvador & U.S. & 1983 & 2005 & 1961 & 2006 & 1970 & 2006 \\
\hline 51 & 642 & Equatorial Guinea (C) & France & 1985 & 2006 & 1961 & 2006 & 1973 & 2006 \\
\hline 52 & 643 & Eritrea & U.S. & - & - & 1961 & 2006 & 1998 & 2006 \\
\hline 53 & 939 & Estonia & Germany & 1993 & 2006 & 1993 & 2006 & 1998 & 2006 \\
\hline 54 & 644 & Ethiopia (C) & U.S. & 1985 & 2006 & 1961 & 2006 & 1970 & 2006 \\
\hline 55 & 819 & Fiji & U.S. & 1974 & 2006 & 1961 & 2006 & 1975 & 2006 \\
\hline 56 & 172 & Finland & Germany & 1960 & 2006 & 1961 & 2006 & 1970 & 2006 \\
\hline 57 & 132 & France & Germany & 1964 & 2006 & 1961 & 2006 & 1970 & 2006 \\
\hline 58 & 646 & Gabon (C) & France & 1968 & 2006 & 1961 & 2006 & 1970 & 2006 \\
\hline 59 & 648 & Gambia, The & U.K. & 1977 & 2006 & 1961 & 2006 & 1971 & 2006 \\
\hline 60 & 915 & Georgia & U.S. & 1995 & 2006 & 1996 & 2006 & 1998 & 2006 \\
\hline 61 & 134 & Germany & U.S. & 1960 & 2006 & 1961 & 2006 & 1970 & 2006 \\
\hline 62 & 652 & Ghana (E) (C) & U.S. & 1964 & 2006 & 1961 & 2006 & 1970 & 2006 \\
\hline 63 & 174 & Greece & 1960-80 U.S.; 1981-Germany & 1960 & 2006 & 1961 & 2006 & 1970 & 2006 \\
\hline 64 & 328 & Grenada & U.S. & 1981 & 2006 & 1961 & 2006 & 1979 & 2006 \\
\hline
\end{tabular}




\begin{tabular}{|c|c|c|c|c|c|c|c|c|c|}
\hline \multirow[b]{2}{*}{65} & \multirow{2}{*}{$\begin{array}{c}\text { Country } \\
\text { Code } \\
\text { (cn) } \\
258\end{array}$} & \multirow{2}{*}{$\begin{array}{l}\text { Country Name } \\
\text { Guatemala (C) }\end{array}$} & \multirow{2}{*}{$\begin{array}{l}\text { Base Country } \\
\text { US }\end{array}$} & \multicolumn{2}{|c|}{$\begin{array}{c}\text { Monetary } \\
\text { Independence (MI) }\end{array}$} & \multicolumn{2}{|c|}{$\begin{array}{l}\text { Exchange rate } \\
\text { stability (ERS) }\end{array}$} & \multicolumn{2}{|c|}{$\begin{array}{l}\text { KA Openness } \\
\text { (KAOPEN) }\end{array}$} \\
\hline & & & & 1960 & 2006 & 1961 & 2006 & 1970 & 2006 \\
\hline 66 & 656 & Guinea (C) & 1960-73 France; 1974-U.S. & 1986 & 2006 & 1961 & 2005 & 1970 & 2006 \\
\hline 67 & 654 & Guinea-Bissau (C) & U.S. & 1975 & 2006 & 1961 & 2006 & 1981 & 2006 \\
\hline 68 & 336 & Guyana (C) & 1960-75 U.K.; 1976-U.S. & 1966 & 2006 & 1961 & 2006 & 1970 & 2006 \\
\hline 69 & 263 & Haiti & U.S. & 1994 & 2006 & 1961 & 2006 & 1970 & 2006 \\
\hline 70 & 268 & Honduras (C) & U.S. & 1979 & 2006 & 1961 & 2006 & 1970 & 2006 \\
\hline 71 & 532 & Hong Kong, China (E) & U.S. & 1982 & 2006 & 1961 & 2006 & 1970 & 2006 \\
\hline 72 & 944 & Hungary $(E)$ & 1960-91 U.S.; 1992-Germany & 1971 & 2006 & 1969 & 2006 & 1998 & 2006 \\
\hline 73 & 176 & Iceland (C) & 1960-90 U.S.; 1991-Germany & 1964 & 2006 & 1961 & 2006 & 1970 & 2006 \\
\hline 74 & 534 & India (E) & 1960-79 U.K.; 1980-U.S. & 1964 & 2006 & 1961 & 2006 & 1970 & 2006 \\
\hline 75 & 536 & Indonesia (E) & U.S. & 1983 & 2006 & 1968 & 2006 & 1970 & 2006 \\
\hline 76 & 429 & Iran, Islamic Rep. (C) & U.S. & 1960 & 2006 & 1961 & 2006 & 1970 & 2006 \\
\hline 77 & 433 & Iraq (C) & U.S. & - & - & 1961 & 2006 & 1970 & 2006 \\
\hline 78 & 178 & Ireland & 1960-78 U.K.; 1979-Germany & 1964 & 2006 & 1961 & 2006 & 1970 & 2006 \\
\hline 79 & 436 & Israel (E) & U.S. & 1982 & 2006 & 1961 & 2006 & 1970 & 2006 \\
\hline 80 & 136 & Italy & Germany & 1964 & 2006 & 1961 & 2006 & 1970 & 2006 \\
\hline 81 & 343 & Jamaica (E) & U.S. & 1961 & 2006 & 1961 & 2006 & 1970 & 2006 \\
\hline 82 & 158 & Japan (L) & U.S. & 1960 & 2006 & 1961 & 2006 & 1970 & 2006 \\
\hline 83 & 439 & Jordan (E) & U.S. & 1966 & 2006 & 1961 & 2006 & 1970 & 2006 \\
\hline 84 & 916 & Kazakhstan & U.S. & 1994 & 2006 & 1994 & 2006 & 1998 & 2006 \\
\hline 85 & 664 & Kenya $(\mathrm{E})$ & U.S. & 1967 & 2006 & 1961 & 2006 & 1970 & 2006 \\
\hline 86 & 826 & Kiribati & Australia & - & - & 1961 & 2006 & 1990 & 2005 \\
\hline 87 & 542 & Korea, Rep. (E) & U.S. & 1964 & 2006 & 1961 & 2006 & 1970 & 2006 \\
\hline 88 & 443 & Kuwait & U.S. & 1975 & 2006 & 1961 & 2006 & 1970 & 2006 \\
\hline 89 & 917 & Kyrgyz Republic & U.S. & 1993 & 2006 & 1994 & 2006 & 1998 & 2006 \\
\hline 90 & 544 & Lao PDR & U.S. & 1979 & 2006 & 1961 & 2006 & 1970 & 2006 \\
\hline 91 & 941 & Latvia & Germany & 1993 & 2006 & 1993 & 2006 & 1998 & 2006 \\
\hline 92 & 446 & $\begin{array}{l}\text { Lebanon } \\
\text { Leno }\end{array}$ & U.S. & 1964 & 2006 & 1961 & 2006 & 1970 & 2006 \\
\hline 93 & 666 & Lesotho & South Africa & 1980 & 2006 & 1961 & 2006 & 1972 & 2006 \\
\hline 94 & 668 & Liberia (C) & U.S. & 1981 & 2006 & 1961 & 2006 & 1970 & 2006 \\
\hline 95 & 672 & Libya (C) & U.S. & 1963 & 2006 & 1961 & 2006 & 1970 & 2006 \\
\hline 96 & 946 & Lithuania (E) & Germany & 1994 & 2006 & 1993 & 2006 & 1998 & 2006 \\
\hline 97 & 137 & Luxembourg & 1960-78 Belgium; 1979- Germany & 1985 & 2006 & 1961 & 2006 & & - \\
\hline 98 & 674 & Madagascar (C) & France & 1970 & 2006 & 1961 & 2006 & 1970 & 2006 \\
\hline 99 & 676 & Malawi (C) & U.S. & 1963 & 2006 & 1961 & 2006 & 1970 & 2006 \\
\hline 100 & 548 & Malaysia (E) & U.S. & 1966 & 2006 & 1961 & 2006 & 1970 & 2006 \\
\hline 101 & 556 & Maldives & U.S. & 1978 & 2006 & 1961 & 2006 & 1982 & 2006 \\
\hline 102 & 678 & Mali (C) & France & 1964 & 2006 & 1961 & 2006 & 1970 & 2006 \\
\hline 103 & 181 & Malta & France & 1969 & 2006 & 1961 & 2006 & 1972 & 2006 \\
\hline 104 & 682 & Mauritania (C) & 1960-73 France; 1974-U.S. & 1964 & 2006 & 1961 & 2005 & 1970 & 1964 \\
\hline 105 & 684 & Mauritius (E) & U.K. & 1967 & 2006 & 1961 & 2006 & 1972 & 1967 \\
\hline 106 & 273 & Mexico (E) & U.S. & 1976 & 2006 & 1961 & 2006 & 1970 & 1976 \\
\hline 107 & 868 & Micronesia, Fed. Sts. & U.S. & 1996 & 2006 & 1961 & 2006 & 1996 & 1996 \\
\hline 108 & 921 & Moldova & U.S. & 1995 & 2006 & 1992 & 2006 & 1998 & 1995 \\
\hline 109 & 948 & Mongolia (C) & U.S. & 1993 & 2006 & 1991 & 2006 & 1998 & 1993 \\
\hline 110 & 686 & Morocco (E) & France & 1969 & 2006 & 1961 & 2006 & 1970 & 1969 \\
\hline 111 & 688 & Mozambique & U.S. & 1994 & 2006 & 1961 & 2006 & 1988 & 1994 \\
\hline 112 & 518 & Myanmar (C) & U.S. & 1975 & 2006 & 1961 & 2006 & 1970 & 1975 \\
\hline 113 & 728 & Namibia (C) & South Africa & 1991 & 2006 & 1962 & 2006 & 1994 & 1991 \\
\hline 114 & 558 & Nepal & 1960-82 U.S.; 1983-India & 1974 & 2006 & 1961 & 2006 & 1970 & 1974 \\
\hline 115 & 138 & Netherlands & Germany & 1960 & 2006 & 1961 & 2006 & 1970 & 1960 \\
\hline 116 & 353 & Netherlands Antilles & U.S. & 1980 & 2006 & 1961 & 2006 & 1970 & 1980 \\
\hline 117 & 196 & New Zealand (C) & Australia & 1969 & 2006 & 1961 & 2006 & 1970 & 1969 \\
\hline 118 & 278 & Nicaragua (C) & U.S. & 1990 & 2006 & 1961 & 2006 & 1970 & 1990 \\
\hline 119 & 692 & Niger (C) & France & 1964 & 2006 & 1961 & 2006 & 1970 & 1964 \\
\hline 120 & 694 & Nigeria (E) (C) & U.S. & 1964 & 2005 & 1961 & 2006 & 1970 & 1964 \\
\hline 121 & 142 & Norway & Germany & 1964 & 2006 & 1961 & 2006 & 1970 & 1964 \\
\hline 122 & 449 & Oman (C) & U.S. & 1980 & 2006 & 1961 & 2006 & 1977 & 1980 \\
\hline 123 & 564 & Pakistan (E) & U.S. & 1964 & 2006 & 1961 & 2006 & 1970 & 1964 \\
\hline 124 & 283 & Panama & U.S. & 1986 & 2006 & 1961 & 2006 & 1970 & 1986 \\
\hline 125 & 853 & Papua New Guinea (C) & 1960-85 Australia; 1986-U.S. & 1974 & 2006 & 1961 & 2006 & 1979 & 1974 \\
\hline 126 & 288 & Paraguay (C) & U.S. & 1990 & 2006 & 1961 & 2006 & 1970 & 1990 \\
\hline 127 & 293 & Peru (E) (C) & U.S. & 1960 & 2006 & 1961 & 2006 & 1970 & 1960 \\
\hline 128 & 566 & Philippines (E) & U.S. & 1964 & 2006 & 1961 & 2006 & 1970 & 1964 \\
\hline 129 & 964 & Poland (E) & Germany & 1991 & 2006 & 1961 & 2006 & 1990 & 1991 \\
\hline 130 & 182 & Portugal & Germany & 1960 & 2006 & 1961 & 2006 & 1970 & 1960 \\
\hline 131 & 453 & Qatar (C) & U.S. & 1980 & 2006 & 1967 & 2006 & 1976 & 1980 \\
\hline
\end{tabular}




\begin{tabular}{|c|c|c|c|c|c|c|c|c|c|}
\hline \multirow[t]{2}{*}{132} & \multirow{2}{*}{$\begin{array}{l}968 \\
\text { Country } \\
\text { Code } \\
\text { (cn) }\end{array}$} & \multirow{2}{*}{$\begin{array}{l}\text { Romania } \\
\text { Country Name }\end{array}$} & \multirow{2}{*}{$\begin{array}{l}\text { U.S. } \\
\text { Base Country }\end{array}$} & \multirow{2}{*}{\multicolumn{2}{|c|}{$\begin{array}{c}1994 \quad 2006 \\
\text { Monetary } \\
\text { Independence (MI) }\end{array}$}} & 1961 & 2006 & 1976 & 1994 \\
\hline & & & & & & \multicolumn{2}{|c|}{$\begin{array}{l}\text { Exchange rate } \\
\text { stability (ERS) }\end{array}$} & \multicolumn{2}{|c|}{$\begin{array}{l}\text { KA Openness } \\
\text { (KAOPEN) }\end{array}$} \\
\hline 133 & 922 & Russian Federation (E) & U.S. & 1995 & 2006 & 1993 & 2006 & 1998 & 2006 \\
\hline 134 & 714 & Rwanda (C) & 1960-73 Belgium; 1974-U.S. & 1966 & 2006 & 1961 & 2006 & 1970 & 2006 \\
\hline 135 & 716 & Sao Tome \& Principe (C) & U.S. & 1989 & 2006 & 1961 & 2006 & 1981 & 2006 \\
\hline 136 & 862 & Samoa & Australia & 1983 & 2006 & 1961 & 2006 & 1975 & 2006 \\
\hline 137 & 135 & San Marino & Germany & - & - & 1961 & 2006 & 1996 & 2006 \\
\hline 138 & 456 & Saudi Arabia (C) & U.S. & 1997 & 2006 & 1961 & 2006 & 1970 & 2006 \\
\hline 139 & 722 & Senegal & France & 1964 & 2006 & 1961 & 2006 & 1970 & 2006 \\
\hline 140 & 718 & Seychelles & U.S. & 1979 & 2006 & 1961 & 2006 & 1981 & 2006 \\
\hline 141 & 724 & Sierra Leone & 1960-77 U.K.; 1978-U.S. & 1966 & 2006 & 1961 & 2006 & 1970 & 2006 \\
\hline 142 & 576 & Singapore (E) & Malaysia & 1972 & 2006 & 1961 & 2006 & 1970 & 2006 \\
\hline 143 & 936 & Slovak Republic (E) & Germany & 1993 & 2006 & 1994 & 2006 & 1998 & 2006 \\
\hline 144 & 961 & Slovenia (E) & Germany & 1993 & 2006 & 1992 & 2006 & 1998 & 2006 \\
\hline 145 & 813 & Solomon Islands (C) & 1960-85 Australia; 1986-U.S. & 1981 & 2006 & 1961 & 2006 & 1982 & 2006 \\
\hline 146 & 726 & Somalia (C) & U.S. & - & - & 1961 & 1989 & 1970 & 2006 \\
\hline 147 & 199 & South Africa (E) & U.S. & 1960 & 2006 & 1961 & 2006 & 1970 & 2006 \\
\hline 148 & 184 & Spain & Germany & 1964 & 2006 & 1961 & 2006 & 1970 & 2006 \\
\hline 149 & 524 & Sri Lanka (E) & 1960-92 U.S.; 1993-India & 1964 & 2006 & 1961 & 2006 & 1970 & 2006 \\
\hline 150 & 361 & St. Kitts and Nevis & U.S. & 1981 & 2006 & 1961 & 2006 & 1988 & 2006 \\
\hline 151 & 362 & St. Lucia & U.S. & 1981 & 2006 & 1961 & 2006 & 1983 & 2006 \\
\hline 152 & 364 & St. Vinc. \& the Gren. (C) & U.S. & 1981 & 2006 & 1961 & 2006 & 1983 & 2006 \\
\hline 153 & 732 & Sudan (C) & 1960-71 U.K.; 1972-U.S. & 1978 & 1984 & 1961 & 2006 & 1970 & 2005 \\
\hline 154 & 366 & Suriname $(\mathrm{C})$ & U.S. & 1991 & 2006 & 1961 & 2006 & 1970 & 2006 \\
\hline 155 & 734 & Swaziland (C) & South Africa & 1974 & 2006 & 1961 & 2006 & 1973 & 2006 \\
\hline 156 & 144 & Sweden & Germany & 1960 & 2006 & 1961 & 2006 & 1970 & 2006 \\
\hline 157 & 146 & Switzerland & Germany & 1964 & 2006 & 1961 & 2006 & 1996 & 2006 \\
\hline 158 & 463 & Syrian Arab Republic & U.S. & 2003 & 2006 & 1961 & 2006 & 1970 & 2006 \\
\hline 159 & 528 & Taiwan (E) & U.S. & 1985 & 2006 & 1983 & 2006 & - & - \\
\hline 160 & 923 & Tajikistan & U.S. & 1997 & 2006 & 1993 & 2006 & 1998 & 2006 \\
\hline 161 & 738 & Tanzania (C) & U.S. & 1973 & 2006 & 1961 & 2006 & 1970 & 2006 \\
\hline 162 & 578 & Thailand (E) & France & 1977 & 2006 & 1961 & 2006 & 1970 & 2006 \\
\hline 163 & 742 & Togo (C) & Australia & 1964 & 2006 & 1961 & 2006 & 1970 & 2006 \\
\hline 164 & 866 & Tonga & 1960-75 U.K.; 1976-U.S. & 1981 & 2006 & 1961 & 2006 & 1989 & 2006 \\
\hline 165 & 369 & Trinidad \& Tobago (E) (C) & France & 1965 & 2006 & 1961 & 2006 & 1970 & 2006 \\
\hline 166 & 744 & Tunisia (E) & U.S. & 1964 & 2006 & 1961 & 2006 & 1970 & 2006 \\
\hline 167 & 186 & Turkey (E) & U.S. & 1964 & 2006 & 1961 & 2006 & 1970 & 2006 \\
\hline 168 & 925 & Turkmenistan (C) & U.S. & - & - & 1994 & 2001 & 1998 & 2006 \\
\hline 169 & 746 & Uganda (C) & U.S. & 1980 & 2006 & 1961 & 2006 & 1970 & 2006 \\
\hline 170 & 926 & Ukraine & U.S. & 1992 & 2006 & 1993 & 2006 & 1998 & 2006 \\
\hline 171 & 466 & United Arab Emirates (C) & Germany & - & - & 1967 & 2006 & 1976 & 2006 \\
\hline 172 & 112 & United Kingdom & U.S. & 1960 & 2006 & 1961 & 2006 & 1970 & 2006 \\
\hline 173 & 298 & Uruguay & U.S. & 1976 & 2006 & 1965 & 2006 & 1970 & 2006 \\
\hline 174 & 846 & Vanuatu & 1960-89 France; 1990-U.S. & 1981 & 2006 & 1961 & 2006 & 1985 & 2000 \\
\hline 175 & 299 & Venezuela, RB (E) (C) & U.S. & 1964 & 2006 & 1961 & 2006 & 1970 & 2006 \\
\hline 176 & 582 & Vietnam (C) & U.S. & 1996 & 2006 & 1961 & 2006 & 1970 & 2006 \\
\hline 177 & 474 & Yemen, Rep. & U.S. & 1996 & 2006 & 1991 & 2006 & 1995 & 2006 \\
\hline 178 & 754 & Zambia (C) & U.S. & 1965 & 2006 & 1961 & 2006 & 1970 & 2006 \\
\hline 179 & 698 & Zimbabwe (E) (C) & U.S. & 1965 & 2005 & 1961 & 2005 & 1984 & 2006 \\
\hline
\end{tabular}

Notes: The base countries are primarily based on Shambaugh (QJE) and complemented by information from IMF's Annual Report on Exchange Arrangement and Exchange Restrictions and CIA Factbook 
Table 1 (a): Tests for Structural Breaks in the Trilemma Indexes

\begin{tabular}{|c|c|c|c|c|c|c|}
\hline & & & 1970-72 & 1974-81 & 1983-96 & 1999-2006 \\
\hline \multirow{9}{*}{$\begin{array}{c}\text { Industrial } \\
\text { Countries (18) }\end{array}$} & \multirow{3}{*}{ Monetary Independence } & Mean & 0.376 & 0.407 & 0.389 & 0.139 \\
\hline & & Change & & +0.031 & -0.018 & -0.250 \\
\hline & & t-stats (p-value) & & $1.31(0.11)$ & $0.85(0.20)$ & $11.91(0.00)^{* * *}$ \\
\hline & \multirow{3}{*}{ Exchange Rate Stability } & Mean & 0.554 & 0.450 & 0.384 & 0.712 \\
\hline & & Change & & -0.104 & -0.066 & +0.328 \\
\hline & & t-stats (p-value) & & $5.24(0.00)^{* * *}$ & $4.88(0.00)^{* * *}$ & $19.59(0.00)^{* * *}$ \\
\hline & \multirow{3}{*}{ Financial Openness } & Mean & 0.439 & 0.469 & 0.688 & 0.955 \\
\hline & & Change & & +0.030 & +0.219 & +0.266 \\
\hline & & t-stats (p-value) & & $1.62(0.07)^{*}$ & $4.34(0.00)^{* * *}$ & $5.27(0.00)^{* * *}$ \\
\hline & & & $1970-72$ & 1974-81 & 1983-96 & 1999-2006 \\
\hline \multirow{9}{*}{$\begin{array}{l}\text { Non-Emerging } \\
\text { Developing } \\
\text { Countries } \\
(32)\end{array}$} & \multirow{3}{*}{ Monetary Independence } & Mean & 0.500 & 0.399 & 0.457 & 0.534 \\
\hline & & Change & & -0.101 & +0.058 & +0.077 \\
\hline & & t-stats (p-value) & & $1.68(0.06)^{*}$ & $1.84(0.04)^{* *}$ & $3.55(0.00)^{* * *}$ \\
\hline & \multirow{3}{*}{ Exchange Rate Stability } & Mean & 0.524 & 0.821 & 0.574 & 0.489 \\
\hline & & Change & & +0.298 & -0.247 & -0.085 \\
\hline & & t-stats (p-value) & & $7.86(0.00)^{* * *}$ & $5.51(0.00)^{* * *}$ & $1.94(0.03)^{* *}$ \\
\hline & \multirow{3}{*}{ Financial Openness } & Mean & 0.267 & 0.365 & 0.326 & 0.391 \\
\hline & & Change & & +0.098 & -0.040 & +0.065 \\
\hline & & t-stats (p-value) & & $5.73(0.01)^{* * *}$ & $2.25(0.02)^{* *}$ & $3.93(0.00)^{* * *}$ \\
\hline & & & 1970-72 & 1974-81 & 1983-96 & 1999-2006 \\
\hline \multirow{9}{*}{$\begin{array}{c}\text { Emerging } \\
\text { Market } \\
\text { Countries } \\
\text { (18) }\end{array}$} & \multirow{3}{*}{ Monetary Independence } & Mean & 0.526 & 0.474 & 0.508 & 0.407 \\
\hline & & Change & & -0.052 & +0.034 & -0.100 \\
\hline & & t-stats (p-value) & & $2.16(0.03)^{* *}$ & $1.42(0.09)^{*}$ & $3.81(0.00)^{* * *}$ \\
\hline & \multirow{3}{*}{ Exchange Rate Stability } & Mean & 0.694 & 0.748 & 0.495 & 0.450 \\
\hline & & Change & & -0.054 & -0.253 & -0.045 \\
\hline & & t-stats (p-value) & & $3.14(0.01)^{* * *}$ & $12.43(0.00)^{* * *}$ & $2.19(0.02)^{* * *}$ \\
\hline & \multirow{3}{*}{ Financial Openness } & Mean & 0.210 & 0.229 & 0.240 & 0.474 \\
\hline & & Change & & +0.020 & +0.010 & +0.234 \\
\hline & & t-stats (p-value) & & $5.03(0.00) * * *$ & $0.40(0.35)$ & $8.88(0.00)^{* * *}$ \\
\hline
\end{tabular}

Note: * significant at $10 \%$; ${ }^{* *}$ significant at $5 \%$; ${ }^{* *}$ significant at $1 \%$ 
Table 1(b): Tests for Structural Breaks in the Trilemma Indexes

\begin{tabular}{|c|c|c|c|c|c|c|}
\hline & & & 1983-89 & 1991-2006 & $1983-2000$ & $2002-2006$ \\
\hline \multirow{9}{*}{$\begin{array}{c}\text { Industrial } \\
\text { Countries (18) }\end{array}$} & \multirow{3}{*}{ Monetary Independence } & Mean & 0.396 & 0.246 & 0.355 & 0.126 \\
\hline & & Change & & -0.150 & & -0.229 \\
\hline & & t-stats (p-value) & & $3.17(0.00)^{* * *}$ & & $5.82(0.00)^{* * *}$ \\
\hline & \multirow{3}{*}{ Exchange Rate Stability } & Mean & 0.402 & 0.543 & 0.422 & 0.727 \\
\hline & & Change & & +0.141 & & +0.290 \\
\hline & & t-stat (p-value) & & $2.05(0.03) * *$ & & $5.61(0.00)^{* * *}$ \\
\hline & \multirow{3}{*}{ Financial Openness } & Mean & 0.578 & 0.905 & 0.748 & 0.949 \\
\hline & & Change & & +0.327 & & +0.201 \\
\hline & & t-stats (p-value) & & $9.22(0.00)^{* * *}$ & & $2.62(0.01)^{* *}$ \\
\hline & & & 1983-89 & 1991-2006 & 1983-2000 & 2002-2006 \\
\hline \multirow{9}{*}{$\begin{array}{l}\text { Non-Emerging } \\
\text { Developing } \\
\text { Countries } \\
(32)\end{array}$} & \multirow{3}{*}{ Monetary Independence } & Mean & 0.421 & 0.522 & 0.483 & 0.517 \\
\hline & & Change & & +0.100 & & +0.034 \\
\hline & & t-stats (p-value) & & $4.80(0.00)^{* * *}$ & & $1.05(0.15)$ \\
\hline & \multirow{3}{*}{ Exchange Rate Stability } & Mean & 0.670 & 0.481 & 0.549 & 0.508 \\
\hline & & Change & & -0.189 & & -0.041 \\
\hline & & t-stats (p-value) & & $7.39(0.00)^{* * *}$ & & $0.78(0.22)$ \\
\hline & \multirow{3}{*}{ Financial Openness } & Mean & 0.296 & 0.376 & 0.336 & 0.400 \\
\hline & & Change & & +0.080 & & +0.064 \\
\hline & & t-stats (p-value) & & $5.94(0.00)^{* * *}$ & & $3.20(0.00)^{* * *}$ \\
\hline & & & 1983-89 & 1991-2006 & $1983-2000$ & 2002-2006 \\
\hline \multirow{9}{*}{$\begin{array}{c}\text { Emerging } \\
\text { Market } \\
\text { Countries } \\
\text { (18) }\end{array}$} & \multirow{3}{*}{ Monetary Independence } & Mean & 0.471 & 0.469 & 0.508 & 0.385 \\
\hline & & Change & & -0.002 & & -0.123 \\
\hline & & t-stats (p-value) & & $0.08(0.47)$ & & $4.52(0.00)^{* * *}$ \\
\hline & \multirow{3}{*}{ Exchange Rate Stability } & Mean & 0.539 & 0.444 & 0.485 & 0.439 \\
\hline & & Change & & -0.095 & & -0.046 \\
\hline & & t-stats (p-value) & & $6.88(0.00)^{* * *}$ & & $1.80(0.04)^{* *}$ \\
\hline & \multirow{3}{*}{ Financial Openness } & Mean & 0.188 & 0.403 & 0.282 & 0.482 \\
\hline & & Change & & +0.215 & & +0.200 \\
\hline & & t-stats (p-value) & & $6.27(0.00)^{* * *}$ & & $4.23(0.00)^{* * *}$ \\
\hline
\end{tabular}

Note: * significant at $10 \%$; ${ }^{* *}$ significant at $5 \%$; ${ }^{* *}$ significant at $1 \%$ 
Table 1(c): Summary of the Structural Breaks Tests

\begin{tabular}{|c|c|c|}
\hline & & Structural Breaks \\
\hline \multirow{3}{*}{$\begin{array}{l}\text { Industrial } \\
\text { Countries } \\
\text { (IDC) }\end{array}$} & Monetary Independence & $1997-98$ \\
\hline & Exchange Rate Stability & $\begin{array}{c}1997-98 \\
\text { (1973 for non-Euro Countries) } \\
\end{array}$ \\
\hline & Financial Openness & 1990 \\
\hline \multirow{3}{*}{$\begin{array}{l}\text { Non-Emerging } \\
\text { Developing } \\
\text { Countries } \\
\text { (NOEMG) }\end{array}$} & Monetary Independence & 1990 \\
\hline & Exchange Rate Stability & 1973 \\
\hline & Financial Openness & 1990 \\
\hline \multirow{3}{*}{$\begin{array}{l}\text { Emerging } \\
\text { Market } \\
\text { Countries } \\
\text { (EMG) }\end{array}$} & Monetary Independence & 2001 \\
\hline & Exchange Rate Stability & 1982 \\
\hline & Financial Openness & 1997-98 \\
\hline
\end{tabular}


Table 2: Regression for the Linear Relationship between the Trilemma Indexes: $1=a_{j} M_{\mathrm{i}, \mathrm{t}}+b_{j} E R S_{\mathrm{i}, \mathrm{t}}+c_{j} K A O P E N_{\mathrm{i}, \mathrm{t}}+\varepsilon_{\mathrm{t}}$

\begin{tabular}{|c|c|c|c|c|c|c|c|c|c|}
\hline & $\begin{array}{c}(1) \\
\text { FULL }\end{array}$ & $\begin{array}{c}(2) \\
1970-72\end{array}$ & $\begin{array}{c}(3) \\
1974-81\end{array}$ & $\begin{array}{c}(4) \\
1983-96\end{array}$ & $\begin{array}{c}(5) \\
1999-2006\end{array}$ & $\begin{array}{c}(6) \\
1983-89\end{array}$ & $\begin{array}{c}(7) \\
1991-2006\end{array}$ & $\begin{array}{c}(8) \\
1983-2000\end{array}$ & $\begin{array}{c}(9) \\
2002-2006\end{array}$ \\
\hline Monetary Independence & $\begin{array}{c}1.356 \\
{[0.041]^{* * *}}\end{array}$ & $\begin{array}{c}1.444 \\
{[0.139]^{* * *}}\end{array}$ & $\begin{array}{c}1.527 \\
{[0.083]^{* * *}}\end{array}$ & $\begin{array}{c}1.279 \\
{[0.063]^{* * *}}\end{array}$ & $\begin{array}{c}0.34 \\
{[0.104]^{* * *}}\end{array}$ & $\begin{array}{c}1.372 \\
{[0.066]^{* * *}}\end{array}$ & $\begin{array}{c}0.687 \\
{[0.113]^{* * *}}\end{array}$ & $\begin{array}{c}1.22 \\
{[0.063]^{* * *}}\end{array}$ & $\begin{array}{c}0.512 \\
{[0.097]^{* * *}}\end{array}$ \\
\hline Exch. Rate Stability & $\begin{array}{c}0.302 \\
{[0.033]^{* * *}}\end{array}$ & $\begin{array}{c}0.402 \\
{[0.084]^{* * *}}\end{array}$ & $\begin{array}{c}0.357 \\
{[0.061]^{* * *}}\end{array}$ & $\begin{array}{c}0.184 \\
{[0.075]^{* *}}\end{array}$ & $\begin{array}{c}0.001 \\
{[0.050]}\end{array}$ & $\begin{array}{c}0.394 \\
{[0.080]^{* * *}}\end{array}$ & $\begin{array}{c}-0.062 \\
{[0.051]}\end{array}$ & $\begin{array}{c}0.151 \\
{[0.061]^{* *}}\end{array}$ & $\begin{array}{c}0.01 \\
{[0.075]}\end{array}$ \\
\hline KA Openness & $\begin{array}{c}0.472 \\
{[0.024]^{* * *}}\end{array}$ & $\begin{array}{c}0.445 \\
{[0.049]^{* * *}}\end{array}$ & $\begin{array}{c}0.306 \\
{[0.066]^{* * *}}\end{array}$ & $\begin{array}{c}0.559 \\
{[0.055]^{* * *}}\end{array}$ & $\begin{array}{c}0.952 \\
{[0.039]^{* * *}}\end{array}$ & $\begin{array}{c}0.385 \\
{[0.066]^{* * *}}\end{array}$ & $\begin{array}{c}0.879 \\
{[0.047]^{* * *}}\end{array}$ & $\begin{array}{c}0.587 \\
{[0.044]^{* * *}}\end{array}$ & $\begin{array}{c}0.913 \\
{[0.044]^{* * *}}\end{array}$ \\
\hline$\overline{\text { ERM x MI }}$ & $\begin{array}{c}-0.445 \\
{[0.088]^{* * *}}\end{array}$ & $\begin{array}{l}- \\
-\end{array}$ & $\begin{array}{c}1.45 \\
{[0.172]^{* * *}}\end{array}$ & $\begin{array}{c}-0.393 \\
{[0.132]^{* * *}}\end{array}$ & $\begin{array}{c}0.183 \\
{[0.132]}\end{array}$ & $\begin{array}{c}0.325 \\
{[0.356]}\end{array}$ & $\begin{array}{c}-0.223 \\
{[0.141]}\end{array}$ & $\begin{array}{c}-0.4 \\
{[0.104]^{* * *}}\end{array}$ & $\begin{array}{c}-0.173 \\
{[0.104]^{*}}\end{array}$ \\
\hline ERM $x$ ERS & $\begin{array}{c}0.025 \\
{[0.049]}\end{array}$ & - & $\begin{array}{l}-0.037 \\
{[0.149]}\end{array}$ & $\begin{array}{c}0.059 \\
{[0.106]}\end{array}$ & $\begin{array}{c}0.123 \\
{[0.063]^{* *}}\end{array}$ & $\begin{array}{c}-0.157 \\
{[0.154]}\end{array}$ & $\begin{array}{c}0.191 \\
{[0.062]^{* * *}}\end{array}$ & $\begin{array}{c}0.092 \\
{[0.077]}\end{array}$ & $\begin{array}{c}0.138 \\
{[0.090]}\end{array}$ \\
\hline ERM x KAOPEN & $\begin{array}{c}0.197 \\
{[0.043]^{* * *}} \\
\end{array}$ & - & $\begin{array}{c}-0.695 \\
{[0.163]^{* * *}}\end{array}$ & $\begin{array}{c}0.128 \\
{[0.073]^{*}}\end{array}$ & $\begin{array}{c}-0.062 \\
{[0.052]}\end{array}$ & $\begin{array}{c}0.024 \\
{[0.218]}\end{array}$ & $\begin{array}{c}-0.005 \\
{[0.058]} \\
\end{array}$ & $\begin{array}{c}0.136 \\
{[0.058]^{* *}}\end{array}$ & $\begin{array}{c}-0.037 \\
{[0.064]}\end{array}$ \\
\hline LDC x MI & $\begin{array}{c}-0.019 \\
{[0.047]}\end{array}$ & $\begin{array}{c}0.176 \\
{[0.160]}\end{array}$ & $\begin{array}{c}-0.353 \\
{[0.117]^{* * *}}\end{array}$ & $\begin{array}{c}0.086 \\
{[0.070]}\end{array}$ & $\begin{array}{c}0.942 \\
{[0.115]^{* * *}}\end{array}$ & $\begin{array}{c}-0.05 \\
{[0.082]}\end{array}$ & $\begin{array}{c}0.654 \\
{[0.117]^{* * *}}\end{array}$ & $\begin{array}{c}0.138 \\
{[0.069]^{* *}}\end{array}$ & $\begin{array}{c}0.811 \\
{[0.110]^{* * *}}\end{array}$ \\
\hline LDC $x$ ERS & $\begin{array}{c}0.021 \\
{[0.036]}\end{array}$ & $\begin{array}{c}-0.281 \\
{[0.093]^{* * *}}\end{array}$ & $\begin{array}{c}0.084 \\
{[0.074]}\end{array}$ & $\begin{array}{c}0.152 \\
{[0.078]^{*}}\end{array}$ & $\begin{array}{c}0.301 \\
{[0.059]^{* * *}}\end{array}$ & $\begin{array}{c}0.001 \\
{[0.085]}\end{array}$ & $\begin{array}{c}0.339 \\
{[0.055]^{* * *}}\end{array}$ & $\begin{array}{c}0.179 \\
{[0.064]^{* * *}}\end{array}$ & $\begin{array}{c}0.288 \\
{[0.084]^{* * *}}\end{array}$ \\
\hline LDC x KAOPEN & $\begin{array}{c}-0.1 \\
{[0.032]^{* * *}} \\
\end{array}$ & $\begin{array}{c}-0.174 \\
{[0.088]^{*}}\end{array}$ & $\begin{array}{c}-0.036 \\
{[0.081]} \\
\end{array}$ & $\begin{array}{c}-0.198 \\
{[0.068]^{* * *}}\end{array}$ & $\begin{array}{c}-0.503 \\
{[0.050]^{* * *}} \\
\end{array}$ & $\begin{array}{c}0.101 \\
{[0.091]}\end{array}$ & $\begin{array}{c}-0.493 \\
{[0.055]^{* * *}} \\
\end{array}$ & $\begin{array}{c}-0.268 \\
{[0.056]^{* * *}} \\
\end{array}$ & $\begin{array}{c}-0.448 \\
{[0.058]^{* * *}}\end{array}$ \\
\hline Observations & 1850 & 150 & 400 & 700 & 400 & 350 & 800 & 900 & 250 \\
\hline Adjusted R-squared & 0.94 & 0.97 & 0.94 & 0.94 & 0.95 & 0.94 & 0.95 & 0.94 & 0.95 \\
\hline
\end{tabular}

Robust standard errors in brackets * significant at $10 \%$; ** significant at $5 \%$; *** significant at $1 \%$

NOTES: ERM is a dummy for the countries and years that correspond to participation in ERM (i.e., Belgium, Denmark, Germany, France, Ireland, and Italy from 1979, Spain from 1989, U.K. only for 1990-91, Portugal from 1992, Austria from 1995, Finland from 1996, and Greece from 1999) 


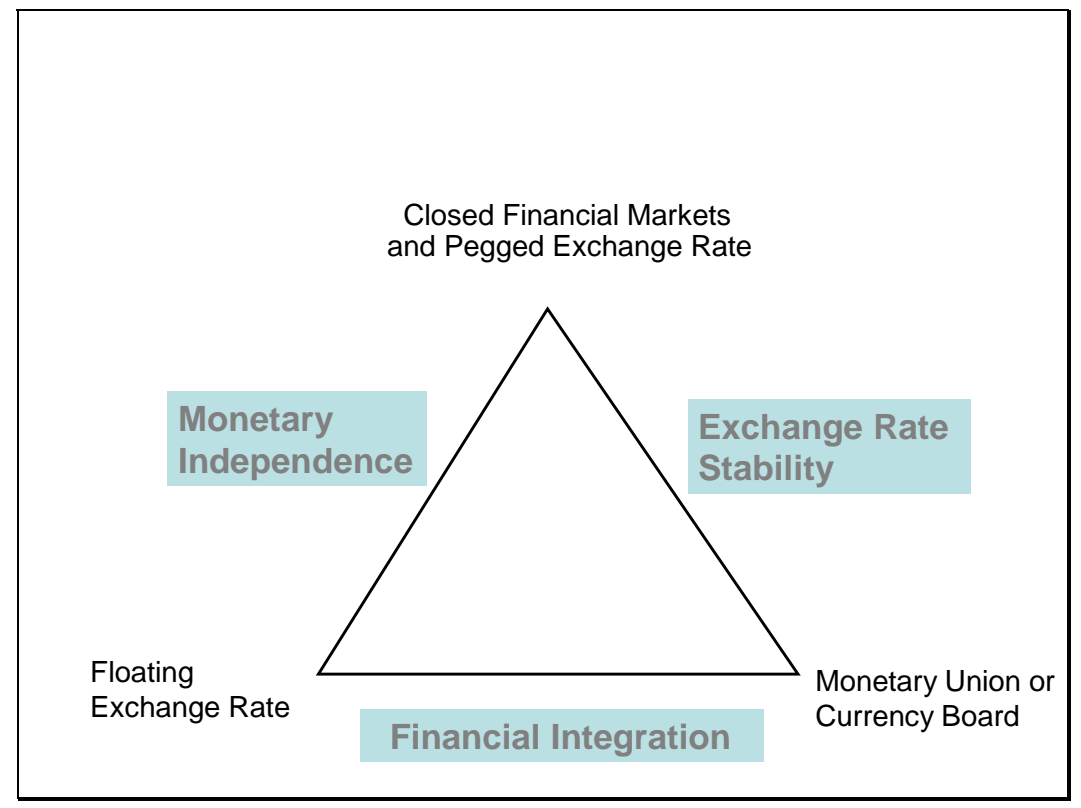

Figure 1: The Trilemma

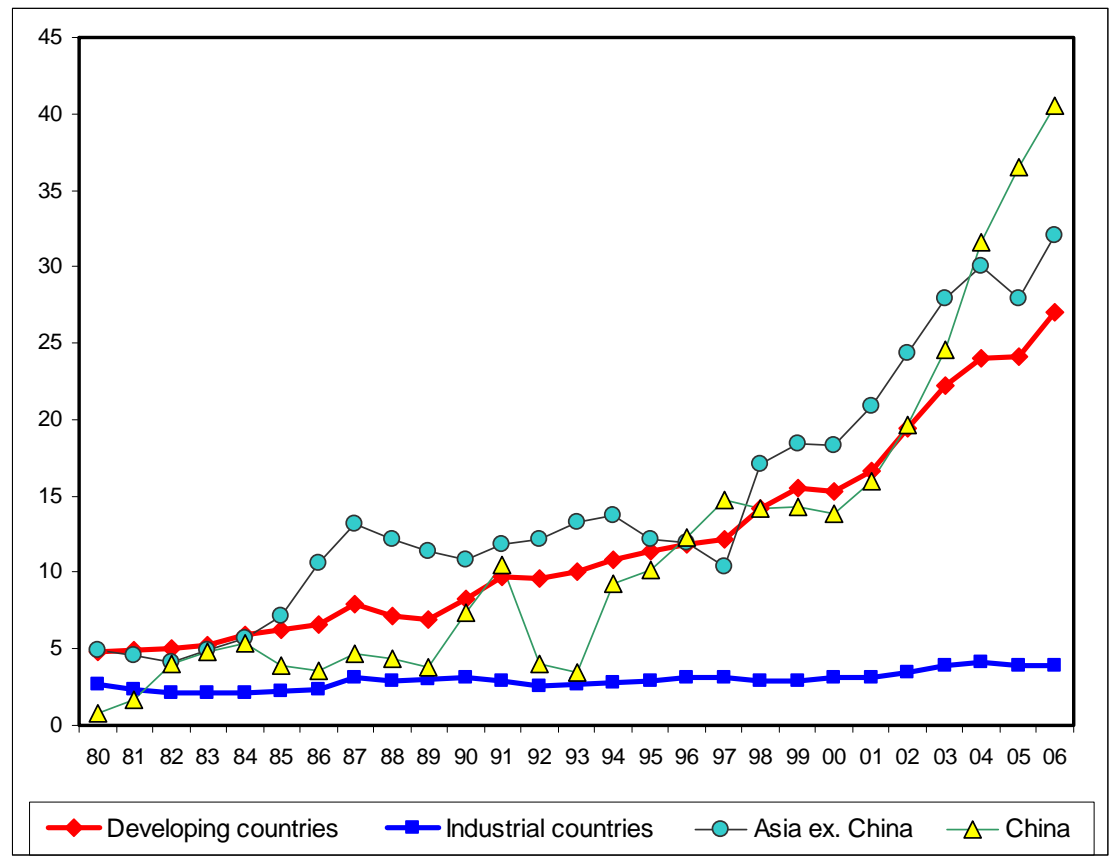

Figure 2: International Reserves/GDP, 1980-2006 


\section{Figure 3: The Trilemma and International Reserves Configurations over Time}

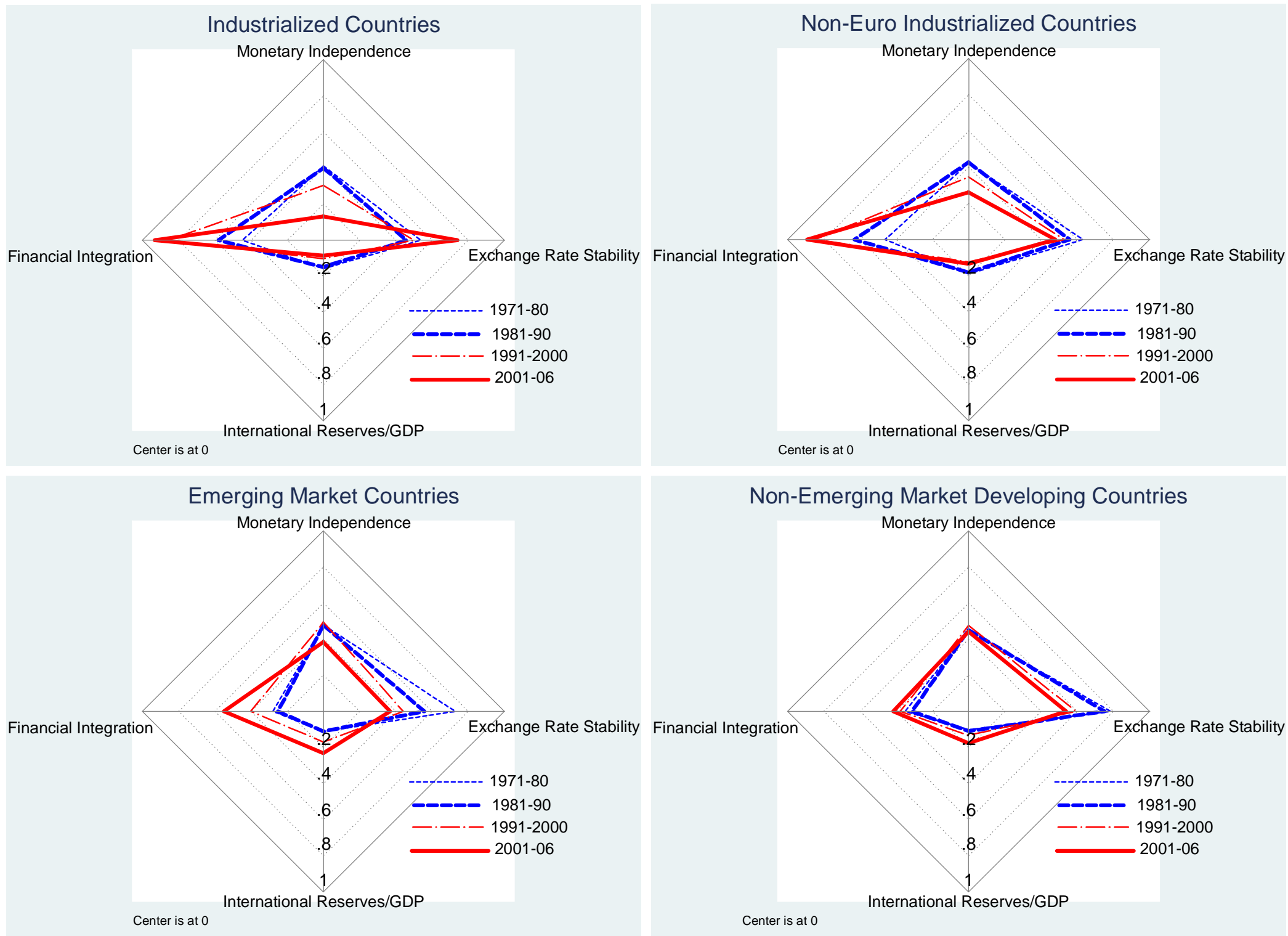


Figure 4: The Trilemma and International Reserves Configurations over Time: Regional Patterns for Developing Countries

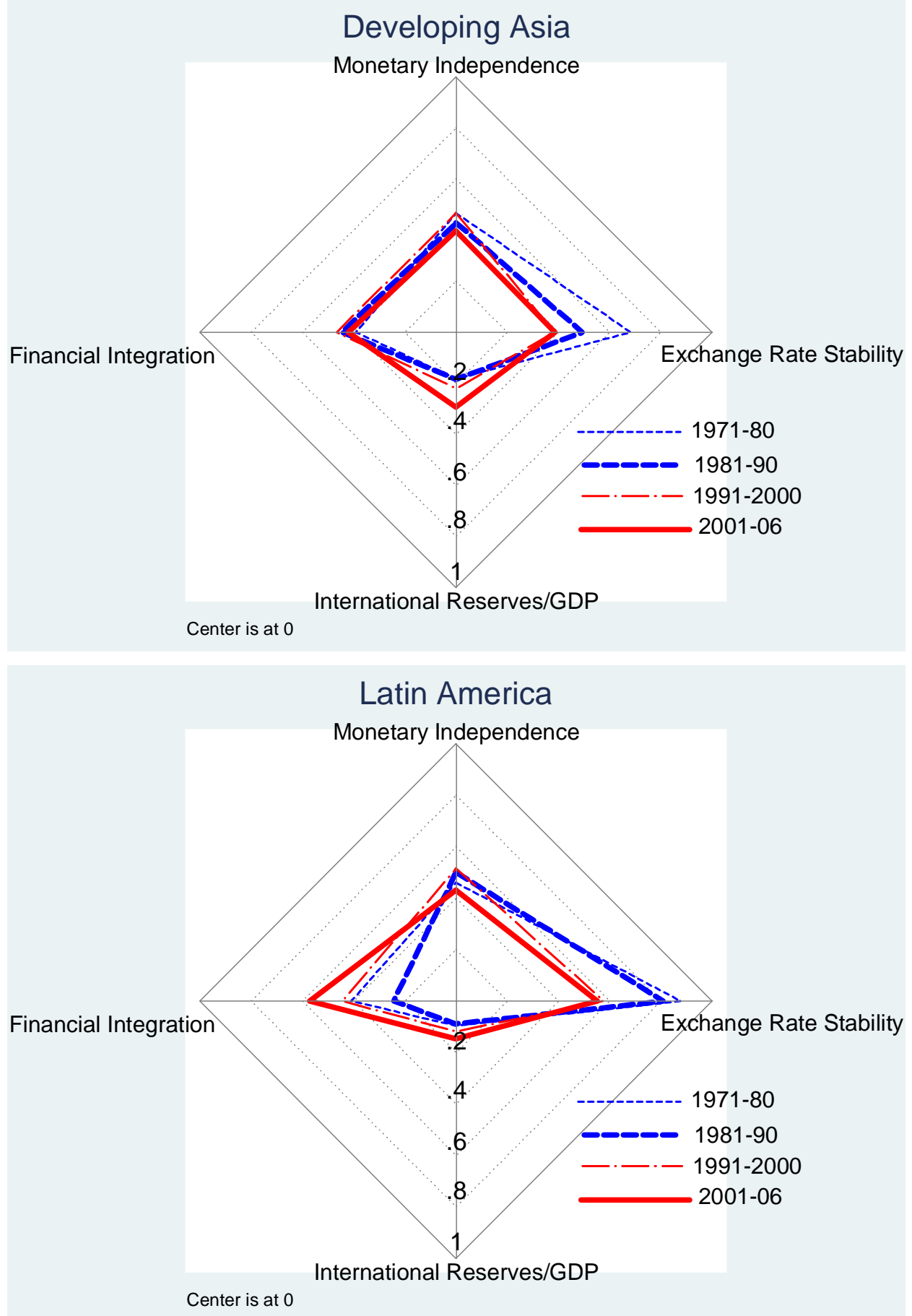


Figure 4 (cont'd): The Trilemma and International Reserves Configurations over Time: Regional Patterns for Developing Countries

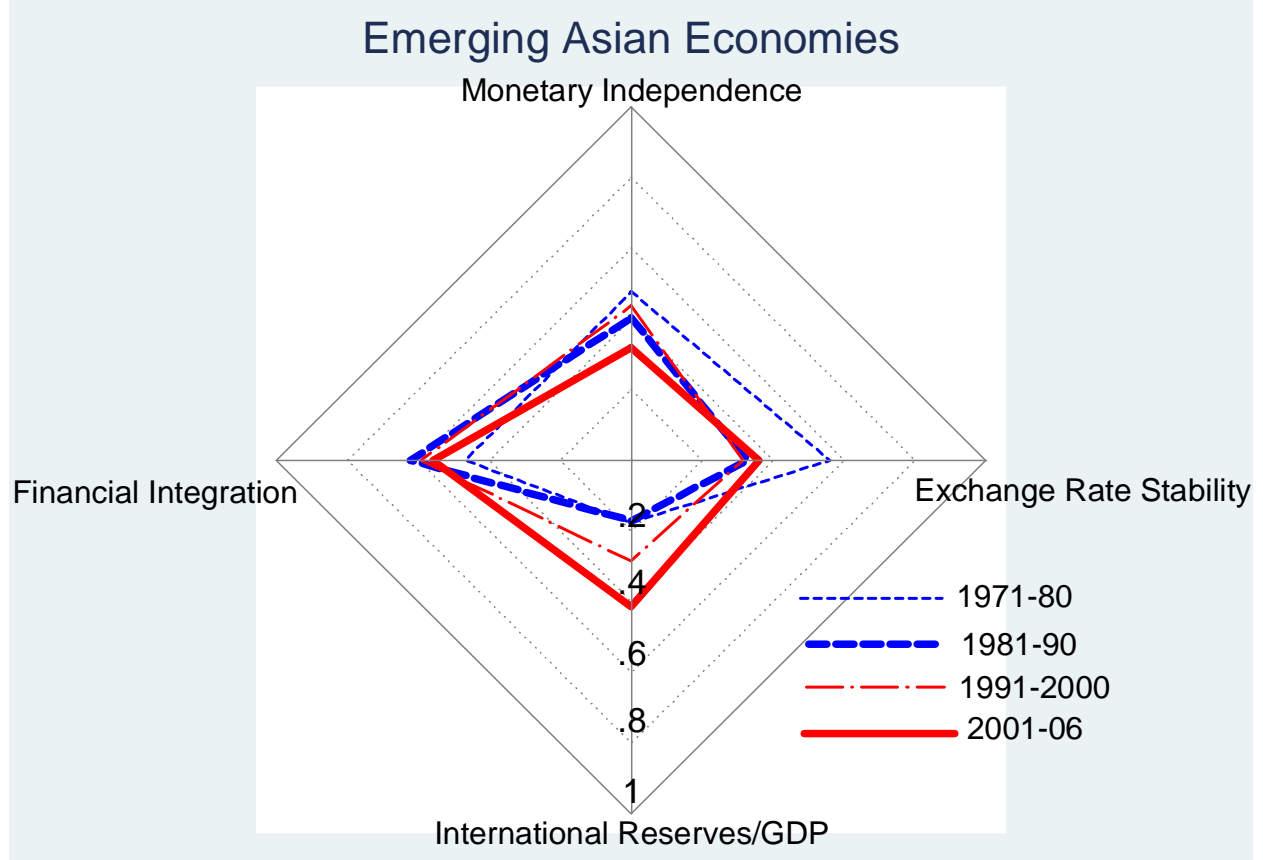

Note: This sample includes Taiwan, HK, Indonesia, Korea, Malaysia, Philipines, Singapore, Thailand, China

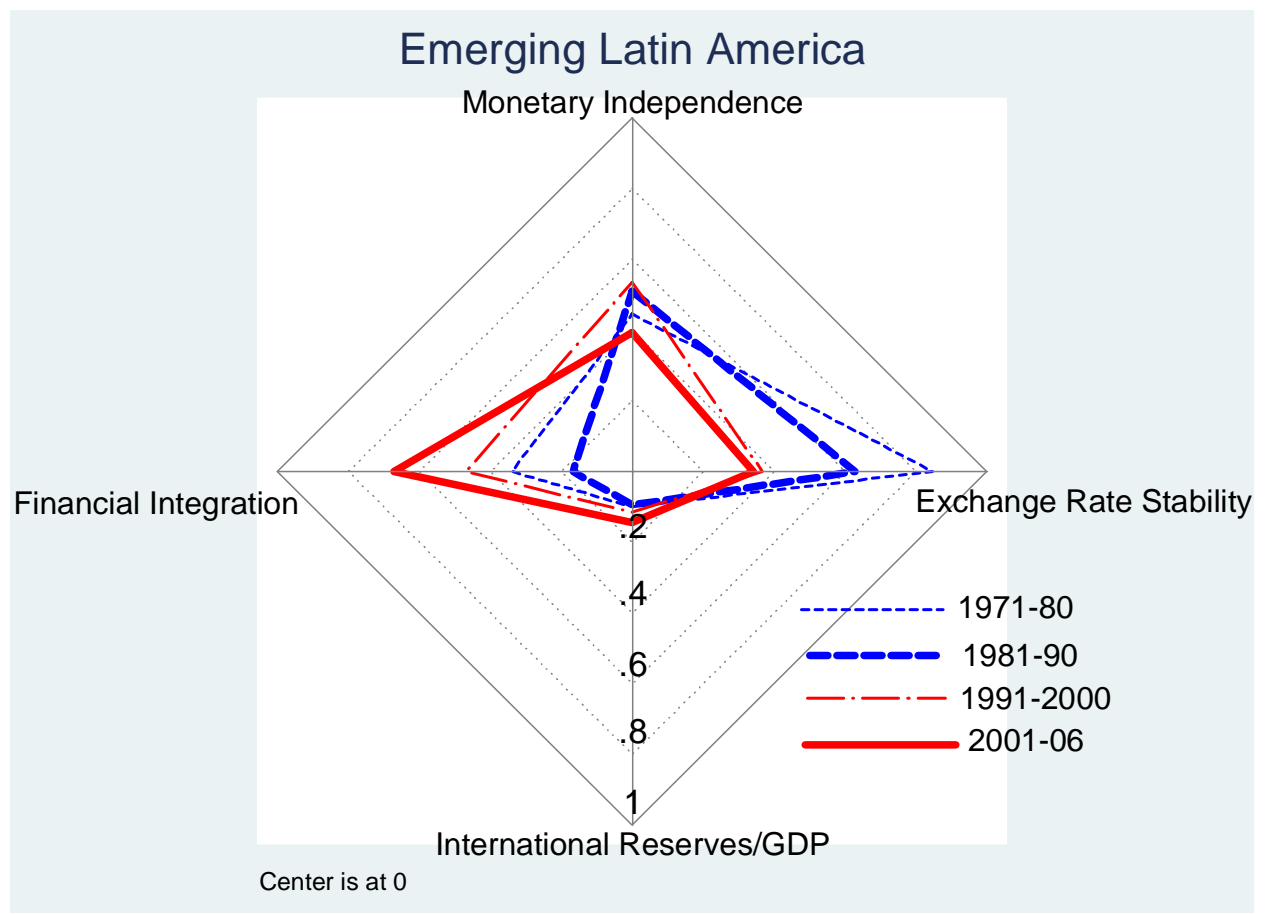

NOTES:

"Emerging Asian Economies” include China, Hong Kong, Indonesia, Korea, Malaysia, Philippines, Singapore, Taiwan, and Thailand.

"Emerging Latin America” includes Argentina, Brazil, Chile, Colombia, Ecuador, Jamaica, Mexico, Peru, Trinidad and Tobago, and Venezuela. 
Figure 4 (cont'd): The Trilemma and International Reserves Configurations over Time: Regional Patterns for Developing Countries
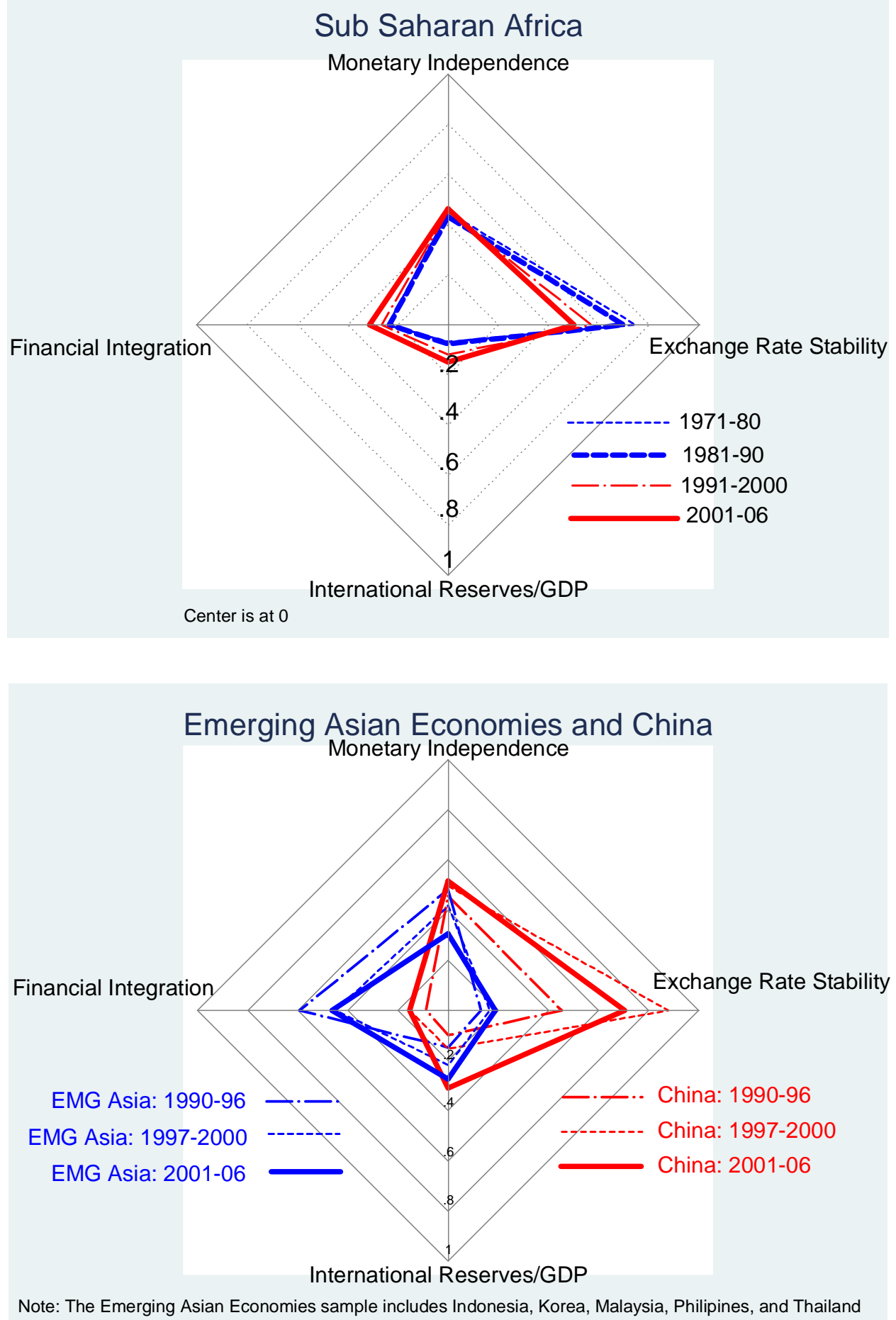


\section{Figure 5: The Evolution of Individual Trilemma Indexes}

(a) Industrialized countries vs. Developing countries
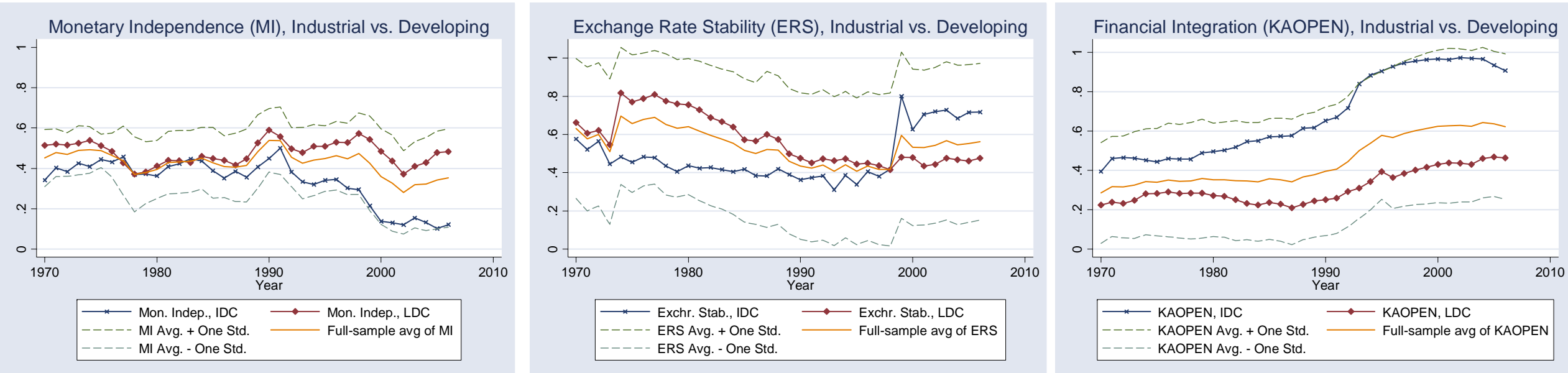

(b) Emerging market countries vs. Non-emerging market, developing countries
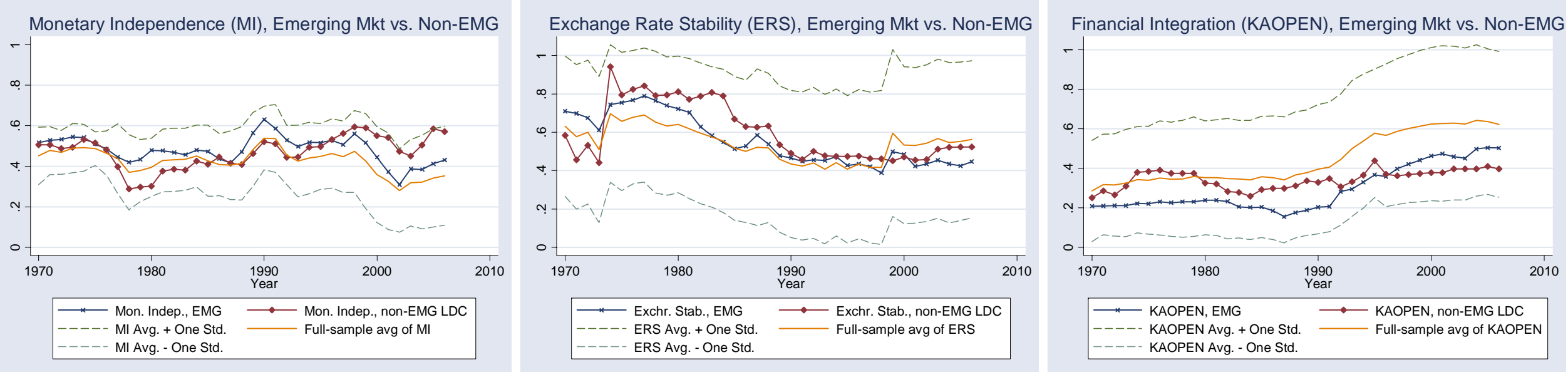
Figure 6: The Evolution of Trilemma Indexes

(a) Industrialized Countries

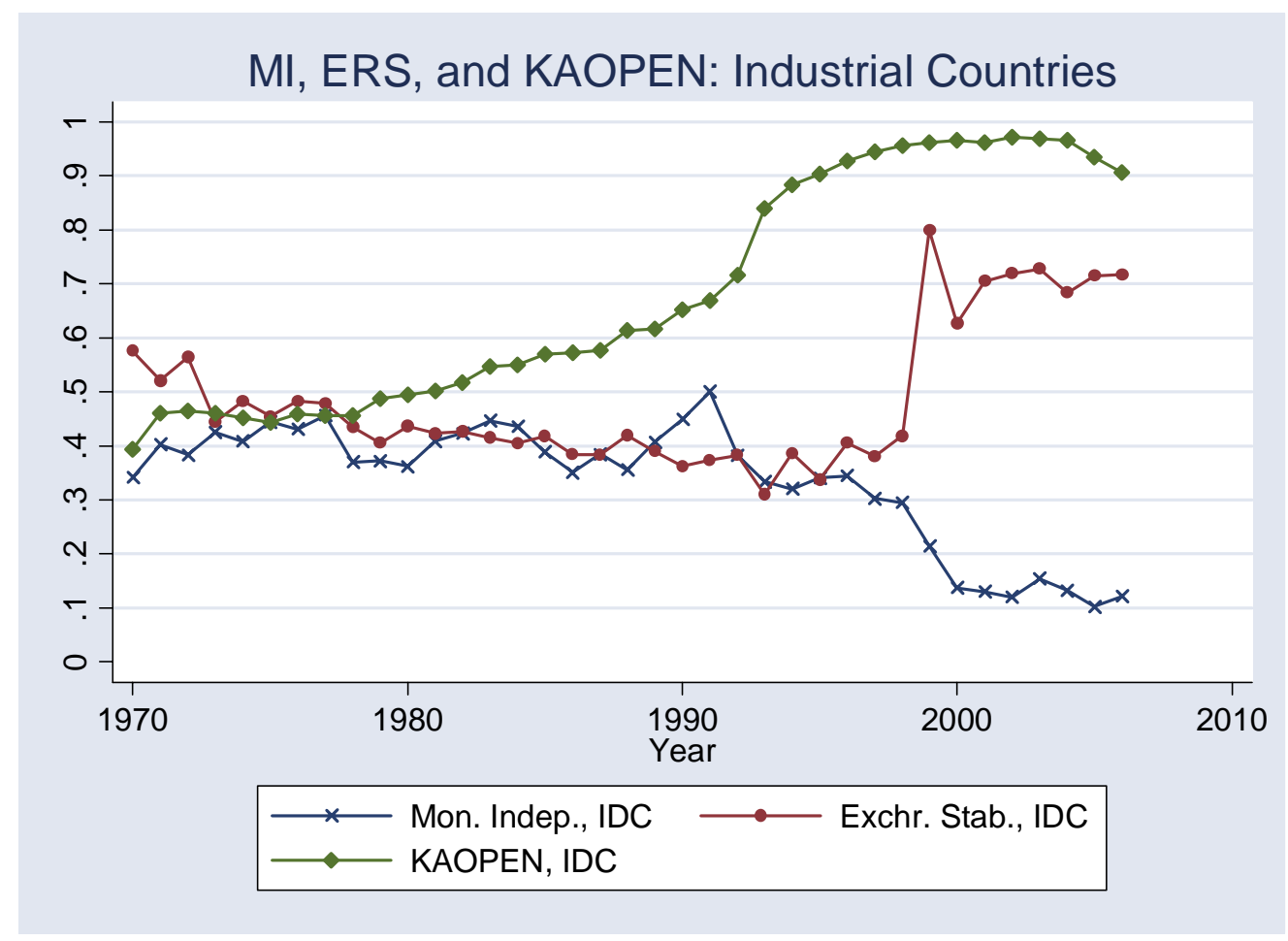

(b) Developing Countries

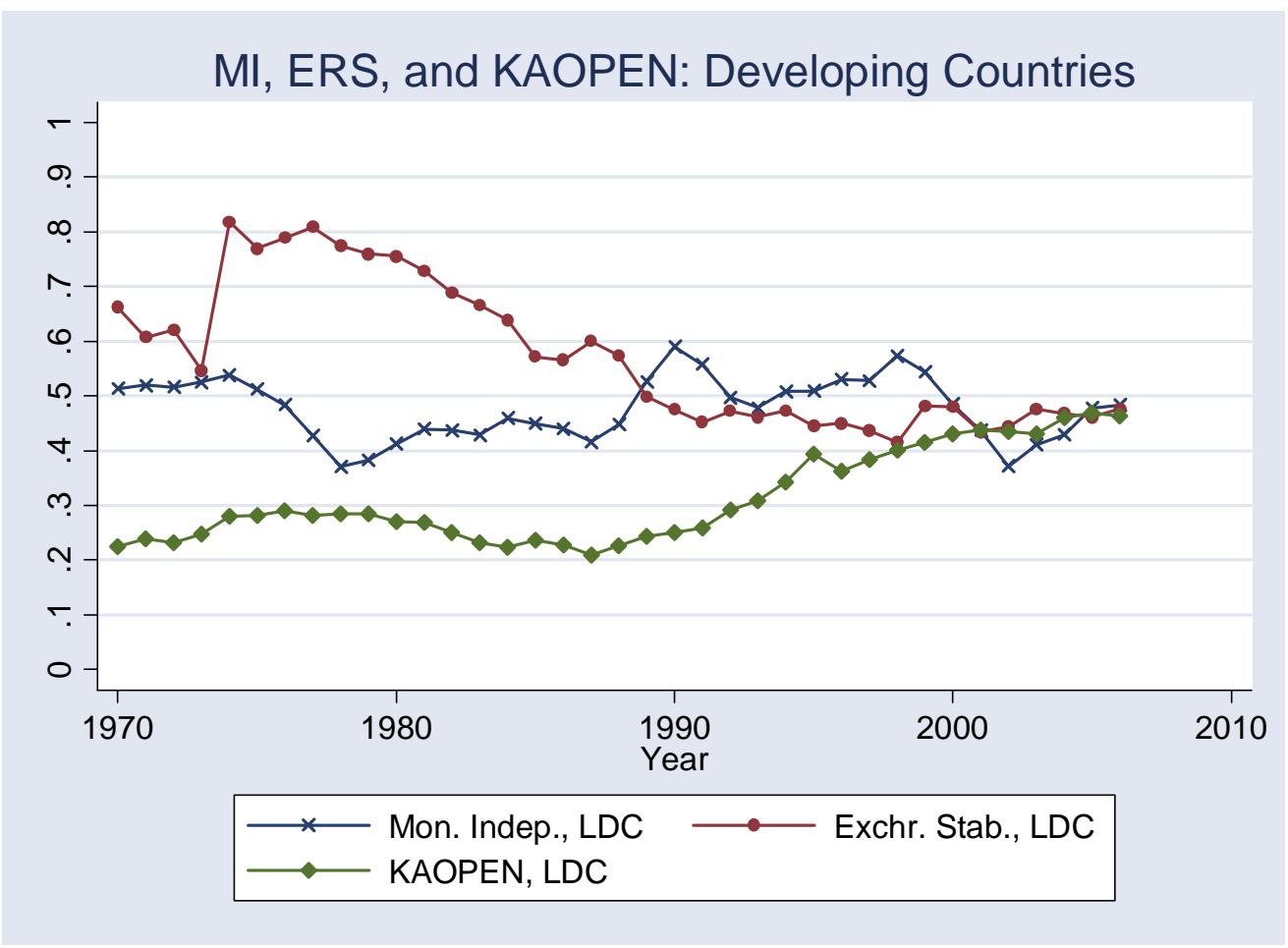




\section{Figure 7: Policy Orientation of IDCs and LDCs}

(a) Cumulative Effects: $(\hat{a} M I+\hat{b} E R S),(\hat{a} M I+\hat{c} K A O P E N),(\hat{b} E R S+\hat{c} K A O P E N)$, and $(\hat{a} M I+\hat{b} E R S+\hat{c} K A O P E N)$

\section{Industrial Countries}

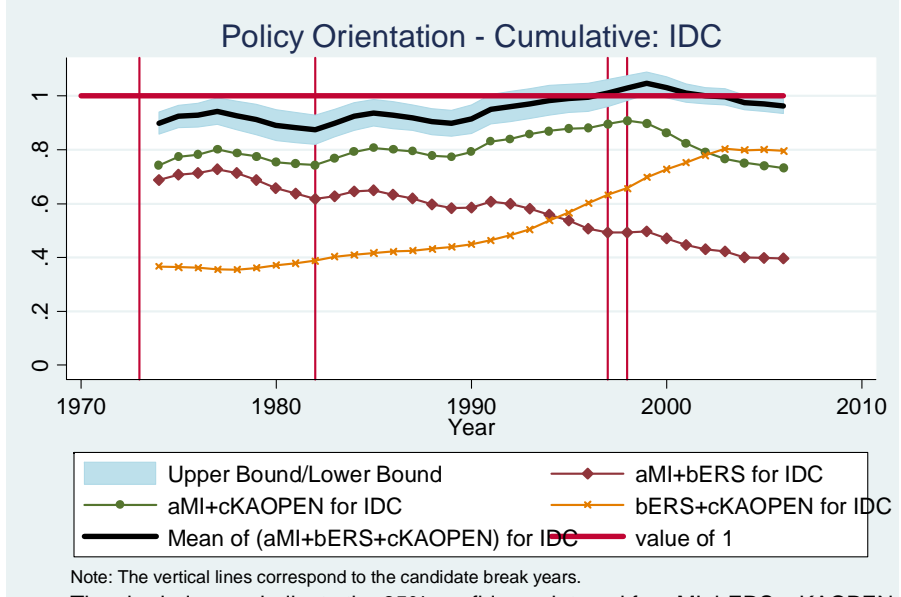

The shaded areas indicate the $95 \%$ confidence interval for aMl+bERS+cKAOPEN.

(b) Individual Effects $\hat{a} M I, \hat{b} E R S$, and $\hat{c} K A O P E N$ Industrial Countries

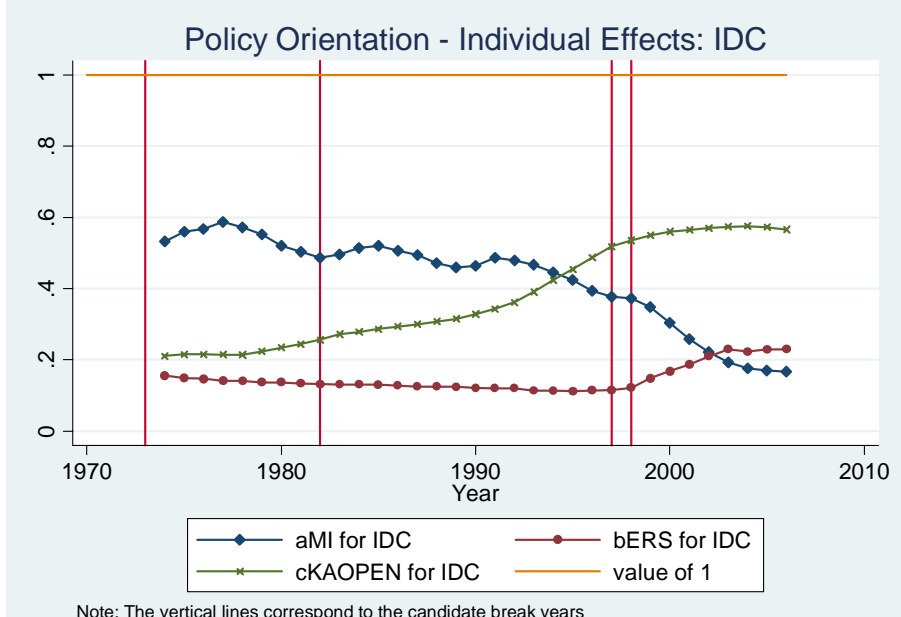

Developing Countries

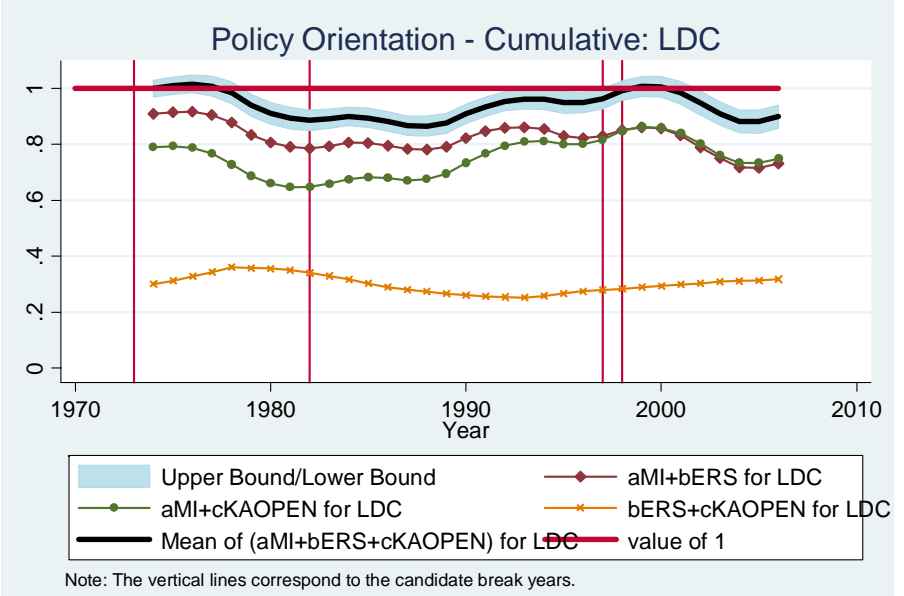

The shaded areas indicate the $95 \%$ confidence interval for aMI+bERS+cKAOPEN.

\section{Developing Countries}

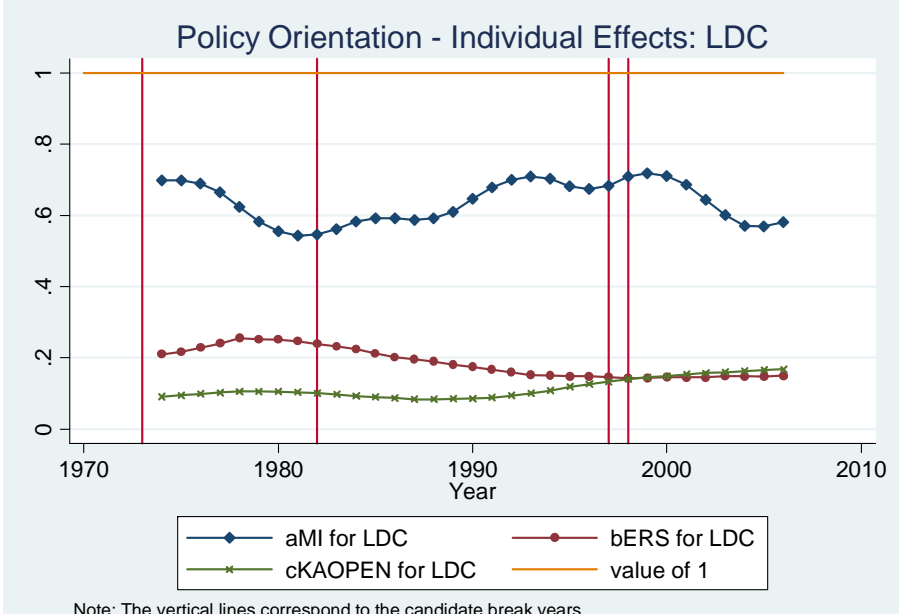

